\title{
Discussion of Influences on Snow Water Equivalent at
}

\section{Utah Snow Courses}

\author{
Randall P. Julander and Jordan A. Clayton \\ Utah Snow Survey, Natural Resources Conservation Service, 245 Jimmy Doolittle Rd., Salt Lake City 84116, UT, USA
}

Received: February 15, 2015/ Accepted: March 05, 2015/ Published: March 202015.

\begin{abstract}
Snow data collection systems in the western United States were originally designed to forecast water supply and may be subject to several sources of bias. In addition to climate change and weather modification effects, site-specific effects may be introduced from vegetation changes, site physical changes, measurement technique, and sensor changes. This paper examines changes in Utah's snowpack conditions over the past decade compared with all previous measurement years, focusing on the 15 snow courses with the longest observational record within the state of Utah. Although patterns in snowpack data consistent with those that would be expected due to temperature increases — such as greater declines at lower elevations and latitudes - were not identified, snow water equivalent decreased at sites with significant increases in vegetation coverage. Additionally, we provide a list of 22 snow courses in Utah that are best-suited for long-term climate analysis.
\end{abstract}

Key words: Snow water equivalent, Utah, snow course, vegetation, changes over time.

\section{Introduction}

SWE (Snow water equivalent) data from two NRCS (Natural Resources Conservation Service), U.S. Department of Agriculture datasets, snow course and SNOTEL (snowpack telemetry), have been used in various research applications as an indicator of climate change in the western U.S. [1-6] and in Utah specifically [7-9]. In addition to decreases in SWE, other researchers have identified changing proportions of snow to rainfall-type precipitation at measurement sites [10-14] and changed timing of annual peak SWE $[6,7,15]$. SWE data from snow courses and SNOTEL sites are also used predicatively-in statistical models to predict snowpack properties at ungaged locations, to model the physical controls on snowpack sensitivity to warming, or to test remote sensing approaches to characterizing snowpack in mountainous terrain - and assume insignificant site-specific changes over time (e.g. vegetation

Corresponding author: Randall P. Julander, M.S., research fields: snow science and hydrology. E-mail: randy.julander@ut.usda.gov. expansion) for measurement sites [16-21].

The goal of this paper is not to contest the findings from these or related studies but simply to emphasize that the snow data collection systems developed by the NRCS were originally designed and continue to be operated to forecast water supply in the western United States [22], and were not necessarily intended for long term climate comparison [23]. In addition to a potential signature from climate change, snow measurement datasets in Utah and the western United States contain systematic and random bias from multiple known sources, including: (1) vegetation changes, such as increases in spatial extent of the forest canopy [2, 23-26] and changes in vegetation type [27-30]. It was recognized very early on that snow accumulation at snow measurement sites would change systematically with changes in forest cover. The NRCS National Engineering Handbook states that "forest cover is a significant factor in snow accumulation and melt at a snow course. Therefore, any change in forest cover may gradually affect the readings obtained over a period of years" [31]. Mahat 
and Tarboton [26] coupled results from a physically-based energy balance model with observations over multiple seasons and concluded that forest areas collected 10-20 percent less snow than adjacent open areas - see detailed review of similar studies in [32]. Additionally, snow course and SNOTEL sites are not typically located in the absolute highest elevations in a particular mountain watershed given the need to shelter the collection sites from winds and access difficulties. As such, sites are commonly located in or below tree-line [33], thereby increasing the potential impact of vegetation increases over the observation period [22]. Additional sources of bias include: (2) site physical changes leading to localized scour or deposition of the snowpack [34, 35] or snow compaction, such as from increases in recreation usage or road relocation near sites [36]; (3) weather modification from cloud seeding [37-39], pollutants [40-42], or dust storms that decrease the snowpack albedo [43, 44]; (4) measurement timing and technique [45-47]; and (5) sensor changes [23, 48]. A detailed review of how each of these potential sources of bias may affect SWE data at snow courses and SNOTEL sites is provided in [36]. As each of these factors may introduce similar-looking biases, site-specific bias features must be quantified before attributing changes over time to any particular cause $[36,45]$.

This paper focuses primarily on the first form of bias presented above: the effect of vegetation changes on SWE data obtained at measurement sites. For 15 example sites, we examine decadal changes in Utah's snowpack to identify patterns that are consistent with warming temperatures in the latter part of the time series. At each, we explore vegetative and physical site change impacts on the associated SWE data that may be responsible for the patterns in the time series. This is accomplished from an analysis of historic photographs and from measurements of SWE taken perpendicular to the standard snow course sample points that establish a gradient of SWE versus vegetation density to determine the impact of vegetation growth on snow accumulation. Our objective is not to attempt to disprove that climate changes are impacting western snowpacks (as is clearly the case), but rather to encourage researchers employing snow course and SWE data to remove systematic biases introduced from local factors [49] to more clearly elucidate whether observed changes are most closely related to global, regional, or local-scale phenomena. Our focus here is on Utah sites given our familiarity with the factors affecting data at these locations and the availability of historical photographs at the snow courses; additional work including the entire western U.S. is warranted. Long-term climate studies from the Sierra Nevada and Cascade mountain ranges in particular strongly suggest that regional climate warming has resulted in a decline in SWE; it is unlikely that the types of local site factors discussed in this paper, if present, produce a significant impact in those regions. However, such analysis is beyond the scope of this contribution.

\section{Methods}

We selected 15 snow course sites in Utah with a variety of site-level factors that underscored the importance of removing the biases described above (Table 1). It should be noted that we made no effort to randomly sample sites according to geography or some other method as our goal was not to attribute long term patterns in SWE to climatic or other factors per se, but rather to quantify the impact of local site factors on SWE and snowfall accumulation. Instead, we simply chose those sites in Utah with the longest observational record. Luckily, the 15 oldest sites are fairly widely distributed across the state and also span low to high elevations. Potential sources of bias at these sites and other details are listed in Table 1. All included sites have observational records that extend back to at least the 1930s and have been continuously monitored to the present. Some of the snow course locations have been upgraded to SNOTEL_or will be 


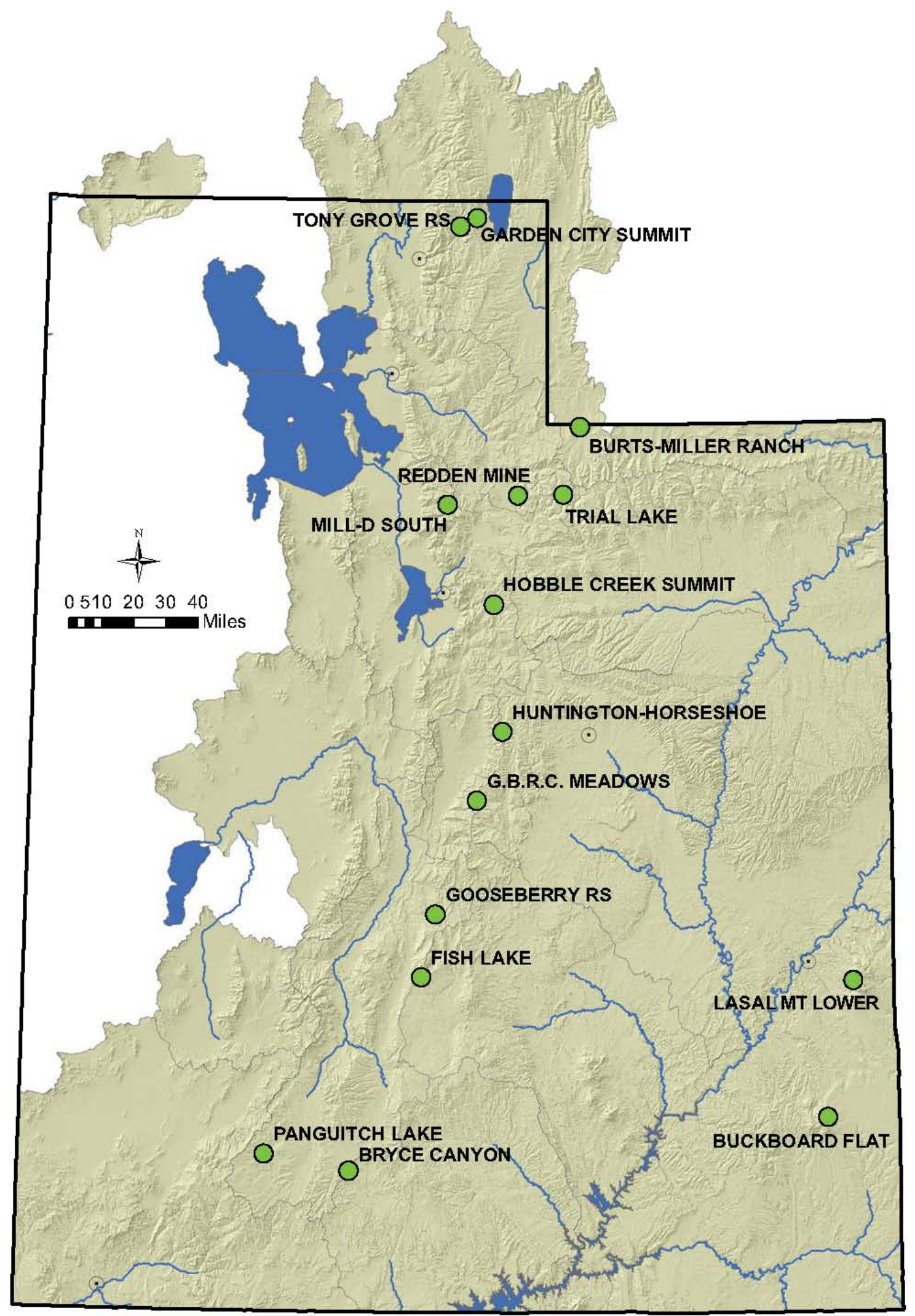

Fig. 1 Locations of snow courses used in this study. These are the 15 snow courses in Utah with the longest observational record. 
Table 1 Site information. All sites are snow courses in Utah, arranged from north to south. * See text for explanation regarding potential site issues [36].

\begin{tabular}{|c|c|c|c|c|c|c|}
\hline Site & Basin & Elevation (m) & Lat. $\mathrm{N}$ & Long. W & Install year & Site issues * \\
\hline Garden City Summit & Little Bear-Logan & 2,316 & 41.92 & -111.47 & 1931 & vegetation, cloud seeding \\
\hline Tony Grove RS & Little Bear-Logan & 1,905 & 41.88 & -111.57 & 1924 & least impacted \\
\hline Burts Miller Ranch & Upper Bear & 2,408 & 41.00 & -110.87 & 1937 & physical, cloud seeding \\
\hline Redden Mine & Upper Weber & 2,591 & 40.68 & -111.22 & 1930 & $\begin{array}{l}\text { vegetation, cloud seeding, } \\
\text { pollution }\end{array}$ \\
\hline Trial Lake & Provo & 3,036 & 40.68 & -110.95 & 1931 & $\begin{array}{l}\text { cloud seeding, } \\
\text { pollution, vegetation }\end{array}$ \\
\hline Mill D South & Jordan & 2,256 & 40.65 & -111.65 & 1935 & cloud seeding, pollution \\
\hline Hobble Creek Summit & Spanish Fork & 2,262 & 40.18 & -111.38 & 1936 & $\begin{array}{l}\text { cloud seeding, } \\
\text { pollution, vegetation }\end{array}$ \\
\hline Huntington Horseshoe & San Rafael & 2,987 & 39.62 & -111.30 & 1930 & least impacted \\
\hline GBRC Meadows & San Pitch & 3,048 & 39.30 & -111.45 & 1930 & least impacted \\
\hline Gooseberry RS & Middle Sevier & 2,560 & 38.78 & -111.68 & 1930 & least impacted \\
\hline Fish Lake & Middle Sevier & 2,652 & 38.50 & -111.77 & 1931 & least impacted \\
\hline Lasal Mt Lower & Colorado & 2,682 & 38.48 & -109.28 & 1931 & vegetation \\
\hline Buckboard Flat & Montezuma & 2,743 & 37.87 & -109.45 & 1930 & vegetation \\
\hline Panguitch Lake & Upper Sevier & 2,521 & 37.70 & -112.65 & 1927 & least impacted \\
\hline Bryce Canyon & East Fork Sevier & 2,438 & 37.63 & -112.17 & 1935 & least impacted \\
\hline
\end{tabular}

within the next few years. SWE will still be measured manually at all sites for the next several years, and comparisons between snow course and SNOTEL data have been shown to be very "clean" [50] and well correlated [7], though an analysis by Cowles [51] indicated that, on average, SNOTEL SWE values were systematically $\sim 1$ inch $(\sim 2.5 \mathrm{~cm})$ higher than equivalent snow course values.

In mountainous areas of the western U.S., most sites achieve their annual maxima in SWE by around the beginning of April, so it has become the convention to use the April 1 SWE values to assess long term trends in snowpack time series data (though there are slight variations in the actual measurement date for snow courses [52, 53] and some researchers question the use of a single date per year [7]. April 1 SWE values are also critically important to confidently predict late spring runoff [54]. Details regarding NRCS standard procedures for measuring SWE are provided in an informational brochure [55], and an excellent review of the challenges inherent in this field sampling methodology is given in Ref. [56]. For the 15 long term snow courses, we compared the average April 1 SWE for each decade (starting in the 1920s and 1930s) to: (1) the average SWE for the period of record and (2) the average SWE for the most recent decade using a standard student's t-test $(\alpha=0.05)$ [7]. Time series data for each site were organized to include the first and last 10 years of record as well as each intermediary decade starting in the zero year and ending in the ninth year. In addition, we compared the most recent 30 year average SWE to both the highest 30 year average and the average SWE for the full period of record. All SWE data were obtained from the NRCS [57]; copies of point observations used to calculate SWE at each snow course are available upon request.

We used a combination of historic photographs (included as Figs. 2, 5, 9, 11, 13, 15, 17, and 19; see also Ref. [58] for a general account of vegetation changes in Utah mountain settings from historical photographs) and SWE transects directed orthogonally to the snow course orientation to evaluate the influence of vegetation on SWE over the long term record. Utilizing photos from 1936 compared to 


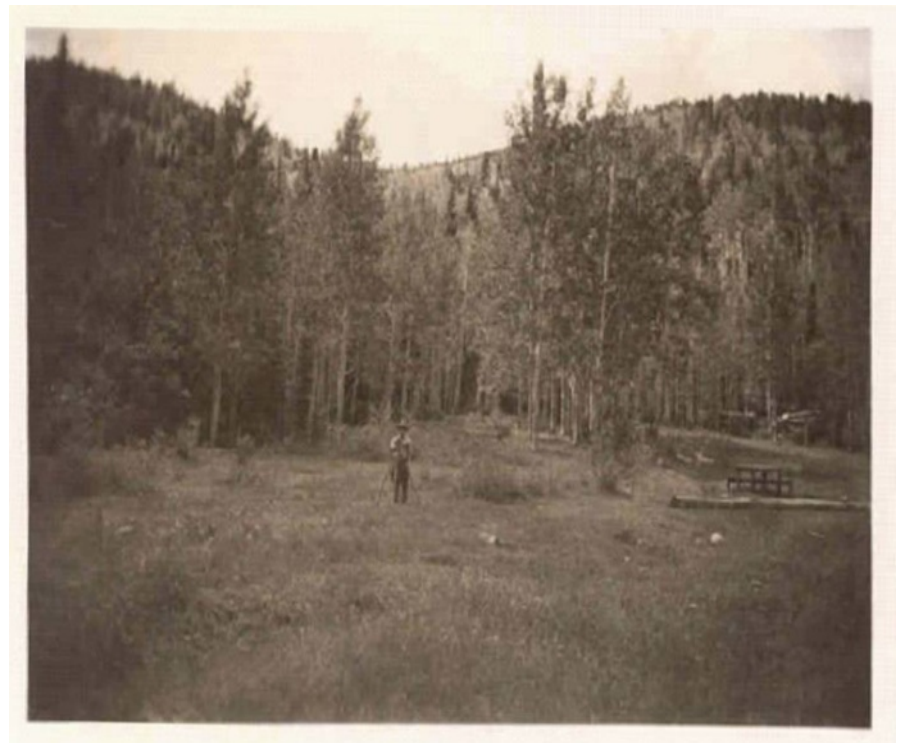

(a)

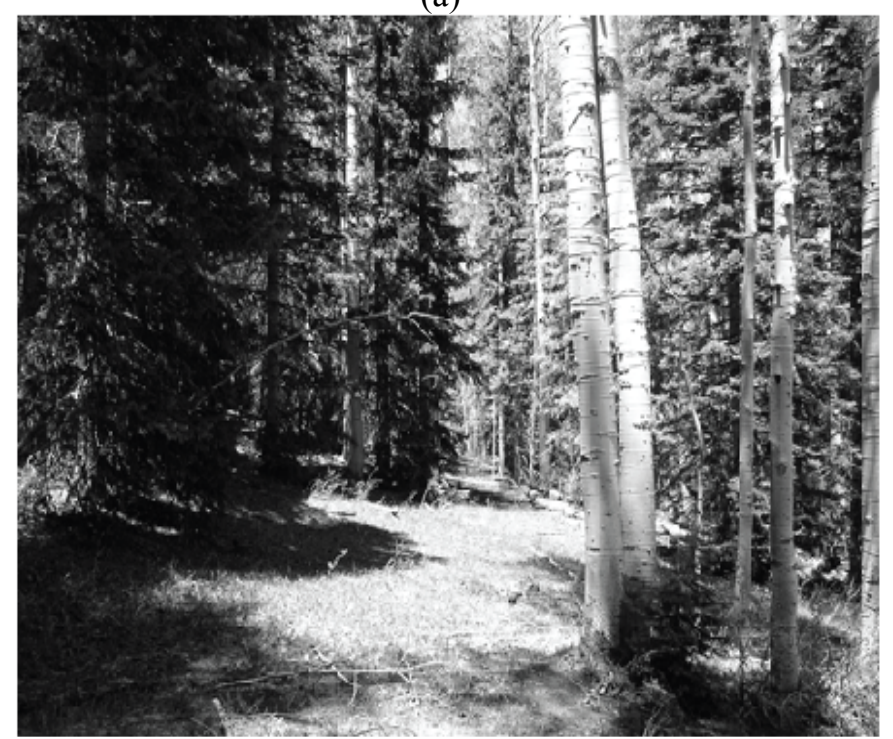

(b)

Fig. 2 Buckboard Flat in 1936 (a) and 2005 (b). The large trees in (b) are in the middle of, or immediately adjacent to, the snow course that was an open meadow in (a). Historical photo from [59], recent photo by authors.

current conditions, snow courses were broken into two separate categories: those with clearly identifiable vegetative or other issues potentially compromising data and those which appear to have remained un-impacted over time. An effort to quantify vegetation increases at each site using a remotely-controlled helicopter and camera is ongoing; this paper includes mainly qualitative assessments of major changes in vegetation cover, such as expansions in forest cover, fires, logging, etc. At sites where vegetation appeared to have changed substantially, SWE measurements were taken every $5 \mathrm{ft}(1.53 \mathrm{~m})$ in a line perpendicular to the each of the snow course stakes at or around April 1 for an average snow year using standard procedures. Values were then averaged for each increment away from the snow course. These transects provided a gradient of SWE from fully vegetated to open areas (similar to the use of comparative snow pits for different vegetation classes, as described by Ref. [26]). 


\section{Results}

\subsection{Variations in SWE over Time}

The first objective was to identify those decades that were significantly different than the period of record mean SWE accumulation for each site. Table 2 presents the average April $1 \mathrm{SWE}$ for each decade as well as the POR average. These data indicate that the 1950s were the wettest period with 4 sites accumulating significantly higher SWE amounts than the POR average. Interestingly, in the 1980s none of the fifteen snow courses had significantly higher SWE accumulation than the POR average, which is surprising given the high snowpack depths and notable snowmelt-driven flooding in Utah in 1983, 1984 and 1986. The 1930s (the Dust Bowl years) had two sites with higher average SWE than the POR, as did the 1940s - all of which were in southern Utah. The 1970s, which includes the driest year on record (1977), had one site with significantly greater SWE than the period of record - the lowest elevation site of the entire group, located in northern Utah.

Contrastingly, for several sites there were numerous decadal periods that had significantly lower SWE than the POR mean, including one site in the $1920 \mathrm{~s}$, three in the 1930s, three in the 1990s, and three in the 2000s. Regional patterns are inconsistent: starting with the 1930s, sites with significantly below average accumulation were in south central and southeastern Utah, whereas both sites with above normal SWE were also in southern Utah. In the 1990s and 2000s, multiple sites had SWE values that were significantly below the POR mean - the majority of these were in northern Utah and were compromised by local factors (as outlined in the following section). All of the above average decadal mean SWE values occurred in the 1970 s or before (most are prior to the 1960s). It is clear that any examination of SWE trends beginning in the 1950s would conclude that SWE values have been declining. Although it would be tempting to draw conclusions about regional factors that may have contributed to the decline in observed SWE at these

Table 2 Mean decadal April 1 SWE (cm) compared to the POR (Period of Record) and most recent decade mean SWE values for 15 long term sites in Utah. Blue and red values are significantly higher and lower than the POR mean, respectively $(\alpha \leq 0.05)$, and + is used to identify values that are significantly higher than the 2002-2011 (most recent decade) mean ( $\alpha \leq$ 0.05). Those sites in the 1930s marked with an * are sites that did not start in 1930 but at a later date and thus are analyzed as a "first ten years of data" site. P-values and other statistical data are available upon request. Sites are arranged from north to south.

\begin{tabular}{|c|c|c|c|c|c|c|c|c|c|c|c|}
\hline Site & 1920 & 1930 & 1940 & 1950 & 1960 & 1970 & 1980 & 1990 & 2000 & $2002-2011$ & POR \\
\hline Garden City Summit & & $44.0 *$ & 41.9 & $53.5+$ & $44.8+$ & $48.3+$ & 41.9 & 34.9 & 35.6 & 37.3 & 42.9 \\
\hline Tony Grove RS & $18.4 *$ & 28.5 & 22.8 & $33.4+$ & 27.7 & $32.6+$ & 28.9 & 24.0 & 23.6 & 27.5 & 26.6 \\
\hline Burts Miller Ranch & & $10.9 *$ & 11.0 & $17.4+$ & $14.5+$ & $14.8+$ & $14.8+$ & 8.0 & 9.3 & 10.9 & 12.9 \\
\hline Redden Mine & & 45.4 & $49.9+$ & $54.4+$ & 46.8 & 44.5 & 47.6 & 43.4 & 39.9 & 42.4 & 46.4 \\
\hline Trial Lake & & $59.9 *$ & 60.7 & $71.3+$ & 58.8 & 60.7 & 65.2 & 57.7 & 54.5 & 57.8 & 61.3 \\
\hline Mill D South & & $50.3 *$ & 48.9 & $56.3+$ & 45.8 & $52.9+$ & 50.9 & 42.9 & 41.3 & 43.2 & 48.6 \\
\hline Hobble Creek Summit & & $35.0 *$ & 33.3 & $39.8+$ & 34.3 & 35.6 & 38.7 & 30.9 & 29.4 & 31.8 & 34.8 \\
\hline Huntington Horseshoe & & 62.8 & $63.8+$ & 64.4 & 57.4 & 58.0 & $70.0+$ & 54.4 & 51.1 & 53.2 & 60.1 \\
\hline GBRC Meadows & & 55.2 & 58.8 & 64.5 & 57.1 & 60.8 & $67.2+$ & 54.8 & 52.7 & 56.5 & 59.2 \\
\hline Gooseberry RS & & 23.7 & 30.4 & 27.5 & 29.6 & 32.3 & $34.0+$ & 25.2 & 26.1 & 27.0 & 28.7 \\
\hline Fish Lake & & $13.7 *$ & 21.9 & 22.2 & 15.6 & 23.1 & $26.6+$ & 17.0 & 16.1 & 18.1 & 19.8 \\
\hline Lasal Mt Lower & & $18.6 *$ & $29.6+$ & $27.4+$ & 23.1 & 25.2 & $27.5+$ & 22.2 & 18.3 & 19.4 & 24.1 \\
\hline Buckboard Flat & & 34.3 & 39.5 & 32.9 & 32.0 & 33.2 & 33.6 & 26.7 & 29.1 & 31.1 & 32.8 \\
\hline Panguitch Lake & & 15.9 & $17.7+$ & 8.5 & 8.2 & 10.6 & 12.0 & 9.0 & 9.1 & 11.6 & 11.6 \\
\hline Bryce Canyon & & $18.1 *$ & 14.4 & 6.8 & 8.5 & 9.0 & 10.4 & 9.2 & 7.6 & 9.9 & 10.4 \\
\hline
\end{tabular}


locations, we outline site-specific factors (below) that have impacted data integrity at these example sites. Again, we acknowledge that we pre-selected sites by age and did not make an effort to ensure that sites were randomly distributed across the state; no effort was made herein to comment on the causes or character of statewide SWE trends over time.

Finally, for all sites the most recent 10 years of data are not statistically different than the POR values, including those that have been compromised by local factors.

We also examined whether SWE values for the most recent decade (2000-2009) were significantly different from any other decadal means. For all of the stations, no decade had significantly lower SWE than the 2000-2009 period, which is not surprising given the persistent drought conditions that have prevailed over this time period. Similarly, the 1930s and 1990s droughts led to comparatively low SWE at all sites; neither of these decades had any sites with significantly different SWE than the most recent decade. Every other decade had multiple sites with significantly higher April 1 SWE accumulation than the 2000-2009 period. The 1950s were very wet by comparison, with eight sites significantly higher than the most recent decadal SWE. Similarly, the 1940s, 1970s, and 1980s had four, four, and six sites with higher SWE than the 2000-2009 period, respectively. Interpretation of these data may lead one to conclude that the recent decade has suffered from a drought similar to other droughts in the full period of record, or that SWE has declined since 1950 at multiple sites. A third explanation - that local factors have generated the apparent drop in SWE for the selected sites-is pursued below.

Finally, we considered differences between 30 year periods for the available data (30 years is the conventional length of record used to determine "percent normal" hydrological conditions at any site). We compared the current 30 year mean (1981-2010) to the highest 30 year span within the full period of record, regardless of when that site's 30 year window happened to have occurred, in order to locate times that were significantly different than the current 30 year mean. Of the 15 snow course sites selected, there are four where the most recent 30 year mean was significantly lower than the highest 30 year mean in the record (Table 3). Of particular note was that three of these four sites had experienced substantial vegetation expansion over the period of record. When comparing the most recent 30 year mean to the period of record mean, only one site (Burts Miller Ranch) was significantly lower, and this was one of the sites that had been compromised due to local factors. By comparison, SWE accumulation at fourteen of the fifteen sites were not significantly different from the POR mean.

Obviously, the date selected as the beginning of the data analysis and the comparative time frame utilized can determine the results and conclusions of any given study. In this case, it is apparent that the most recent two decades were relatively dry but not out of the expected variability for SWE accumulation. In a longer term context (30 yr window) only one site was found to have significantly lower April 1 SWE than the POR average, and that site's data suffer from a physical change that has impacted data integrity over time; an examination of this and other local factors at the 15 selected Utah snow courses follows.

\subsection{Site Changes and Impacts on SWE Data}

The main objective of this paper is to reinforce that site-specific changes may introduce bias into SWE and other snowpack data delivered by snow courses and SNOTEL sites, and to demonstrate how gradual increases in vegetation coverage over time influenced the observed changes in the time series data described above. As other studies have documented connections between climatic changes and snowpack properties, as well as the effect of removing vegetation on snow accumulation (see Introduction), our focus instead is on illustrating how changes at these sites serve as 
Table 330 year April 1 SWE means (cm) compared to the POR and the highest 30 year window for 15 long term sites in Utah. Red values are significantly lower than the highest 30 year window, and - is used to identify values that are significantly lower than the POR mean $(\alpha \leq 0.05)$. P-values and other statistical data are available upon request. Sites are arranged from north to south.

\begin{tabular}{llll}
\hline Site & High & POR & Current \\
\hline Garden City Summit & 50.01 & 42.93 & $\mathbf{3 7 . 4 9}$ \\
Tony Grove RS & 29.72 & 26.64 & 26.57 \\
Burts Miller Ranch & 15.67 & 12.83 & $\mathbf{1 0 . 2 9}-$ \\
Redden Mine & 47.73 & 46.43 & 43.51 \\
Trial Lake & 64.74 & 61.29 & 59.03 \\
Mill D South & 52.63 & 48.64 & $\mathbf{4 4 . 8 3}$ \\
Hobble Creek Summit & 37.52 & 34.77 & 32.99 \\
Huntington Horseshoe & 63.91 & 60.15 & 58.27 \\
GBRC Meadows & 63.63 & 59.21 & 58.95 \\
Gooseberry RS & 31.93 & 28.65 & 28.30 \\
Fish Lake & 23.57 & 19.81 & 20.47 \\
Lasal Mt Lower & 26.70 & 24.08 & $\mathbf{2 1 . 8 4}$ \\
Buckboard Flat & 36.14 & 32.82 & $\mathbf{2 9 . 7 4}$ \\
Panguitch Lake & 14.27 & 11.58 & 10.36 \\
Bryce Canyon & 11.46 & 10.41 & 9.19 \\
\hline
\end{tabular}

examples of how SWE data may become biased due to local factors. Our observations are consequently anecdotal, substantiated by comparisons between historical photographs where available.

Of the 15 longest-term snow course sites in Utah, we identify strong potential for bias in SWE data due to local factors at the following locations: Burts Miller Ranch, Mill D South, Buckboard Flat, Hobble Creek, Garden City Summit, Lasal Mt Lower, Redden Mine, Trial Lake, and Tony Grove RS. Vegetative impacts over the $80^{+}$year observational record were common but other impacts, such as sub irrigation and road building, were also noted. Details for each site follow.

Changes in vegetation coverage have likely impacted April 1 SWE values at Trial Lake, Garden City Summit, Redden Mine, Buckboard Flat, and Lasal Mt Lower. For example, the snow course at Buckboard Flat has changed from an open meadow in the 1930s to a near-closed canopy spruce/fir complex in recent years (Fig. 2). A recent site visit to the Buckboard Flat snow course revealed very large (> $0.5 \mathrm{~m}$ diameter) aspen trees that were growing in the middle of the snow course; these trees were not present when the snow course was first established and would be expected to gradually decrease the snow catch over time as the size of the trees and corresponding canopy increased. In Fig. 3, one can see the result of SWE measurements taken perpendicular to a more open section of the Buckboard Flat snow course, expressed as a percentage of the corresponding snow course value. Within a very short distance $(\sim 3$ $\mathrm{m})$, SWE values decline by roughly $10 \%$ to $15 \%$ in either direction from the snow course. The snow course itself has likely lost up to around $20 \%$ of its April 1 SWE compared to the early period of record (Table 2 and Fig. 3b), likely due to vegetation encroachment.

The Garden City Summit site is located at an elevation of 2,316 m and has a northerly aspect. Fig. 4 and Table 2 show the 10 and 30 year moving averages and the decadal trend, respectively, for the site's snow course data. A steady and very consistent decline in SWE since the 1950's peak suggests that a gradual process has been impacting the data from this site for much of the period of record. This snow course started along a dirt road in an open aspen complex with a few 

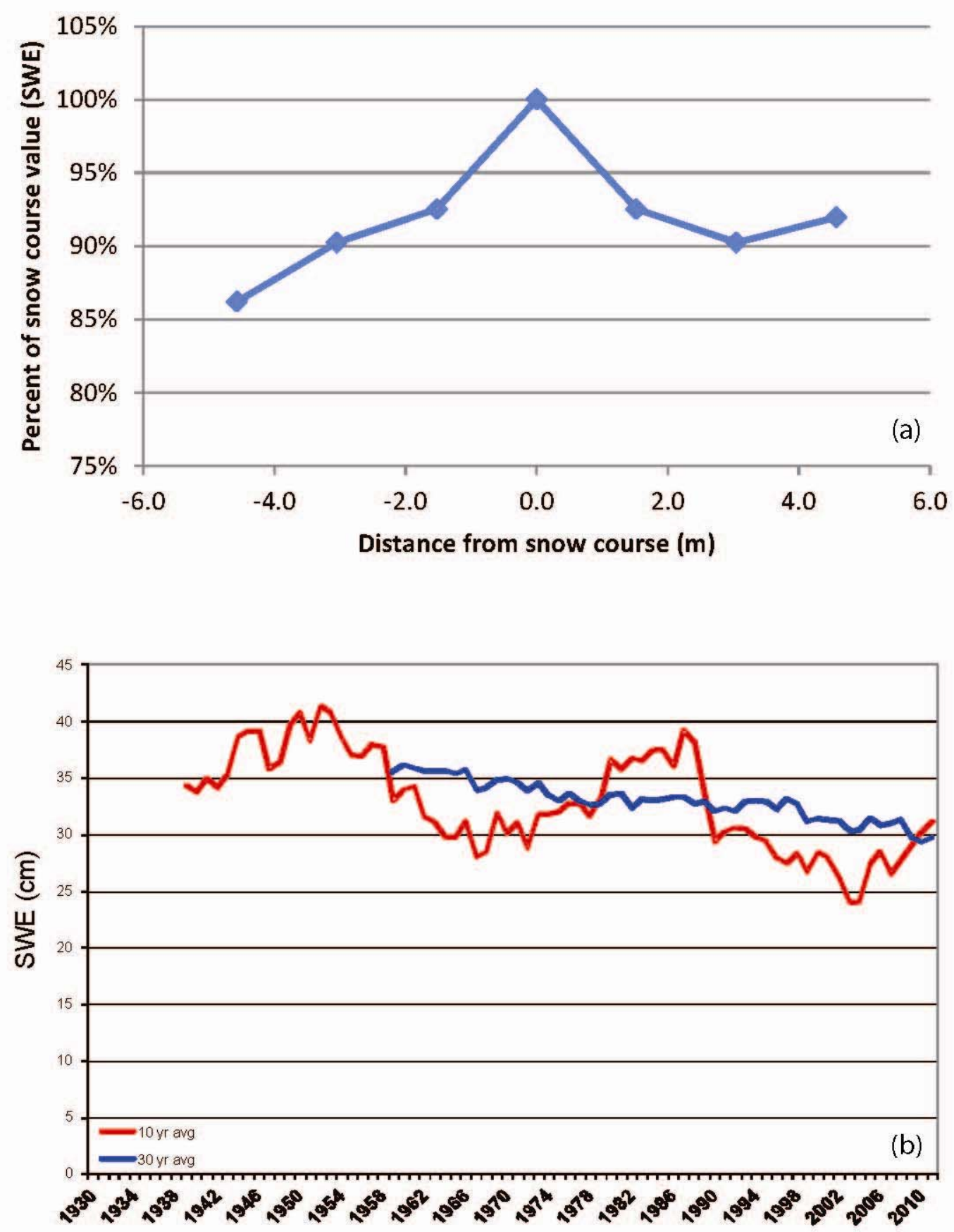

Fig. 3 (a) SWE measurements taken perpendicular to the Buckboard Flat snow course compared to the SWE from the snow course (as a \%). The distance location "0" corresponds with the snow course location. Data were obtained in March, 2009. (b) Buckboard Flat, 10 and 30 year moving averages, April 1 SWE.

nearby conifers (Fig. 5a). Since then, this site has transitioned to a closed conifer forest (Fig. 5b and c). In 2009, a SNOTEL site (ID 1114) was installed in conjunction with the snow course in an opening a short distance (10 meters) away, and is therefore unaffected by the conifers. Since 2009, the SNOTEL site has accumulated $20 \%$ to $25 \%$ more SWE than the snow course, which is roughly the same as the amount of SWE that has decreased over the snow course's period of record. Brown et al. [61] demonstrate that vegetation encroachment produces gradual declines in water yields; the steady reduction in SWE values at 


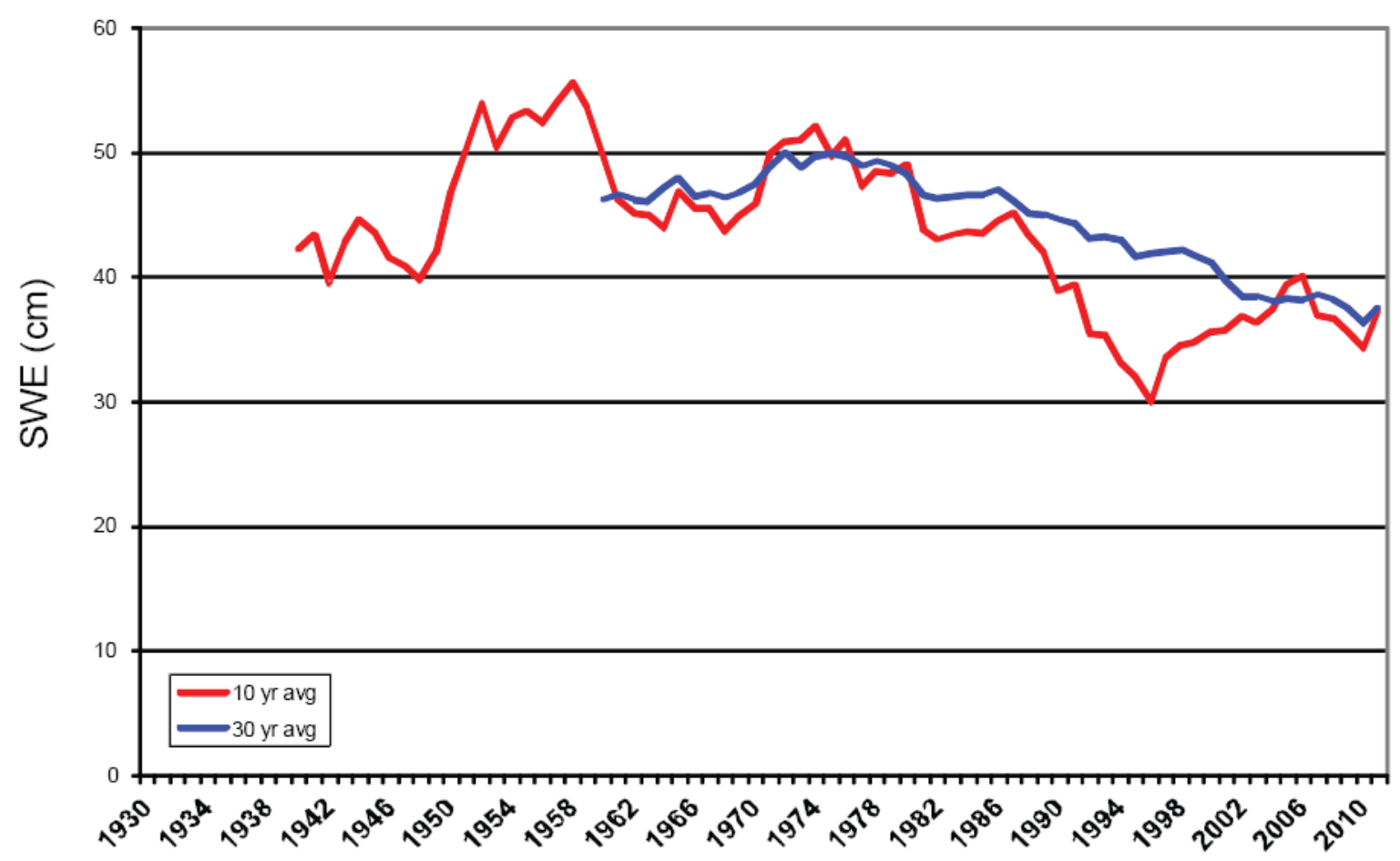

Fig. 4 Garden City Summit, 10 and 30 year moving averages, April 1 SWE.

the Garden City Summit site are suggestive of the impact of increasing vegetation coverage in this area.

The same is true for the Trial Lake snow course, although not to the same extent. The Trial Lake site is on the west edge of a small meadow at $3,042 \mathrm{~m}$ elevation, surrounded on all sides by forest (Fig. 6). Coniferous vegetation at this site has encroached from the west approximately 3 to $5 \mathrm{~m}$ toward the snow course (see extensive notes and documentation in [62]). There has been a small but detectable decline of roughly $5 \%$ to $10 \%$ of April 1 SWE. Given the increase in vegetation coverage over time and the fact that the site is very high elevation, near timberline, and well-shaded, it is unlikely that the observed decreases in SWE have been caused by temperature increases alone. SWE at this course has been measured perpendicular to the snow course several times with the same general result, as given in Fig. 7. These data indicate that if one moves only 1.5 meters to the west toward the encroaching conifers, nearly $20 \%$ of the April 1 SWE is lost (left side of Fig. 7). By contrast, as one moves incrementally into the meadow area of this course (right side of Fig. 7), SWE increases until the intersection with a small stream in the middle of the meadow (which decreases SWE).

Redden Mine, at $2591 \mathrm{~m}$ elevation, has experienced around a 14\% decline in SWE (Fig. 8, $30 \mathrm{yr}$ avg). This site has changed from an open meadow to an aspen grove with trees 6 to $15 \mathrm{~m}$ tall (Fig. 9). Two of the sample points in the snow course (number 2 and 4) appear to have been most strongly affected by the change in vegetation over time (decrease in SWE is statistically significant for these locations, $\alpha=0.05$ ); vegetation increases were also most pronounced at these locations.

At Lasal Mt Lower (2,682 m elevation) there has been around a $12 \%$ decline in SWE (Fig. 10, $30 \mathrm{yr}$ avg) that is likely due to increased vegetation cover combined with a change in vegetation type. This site has transitioned from primarily sage, rabbit brush, and other low shrubs to a rather open, grassy meadow (Fig. 11). Snow that would normally accumulate to the top 


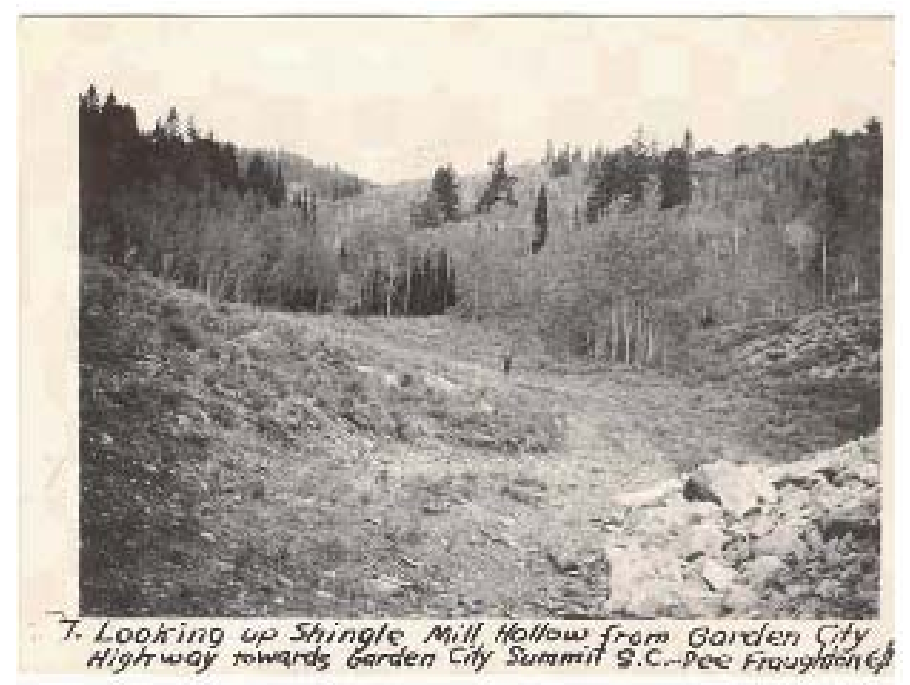

(a)

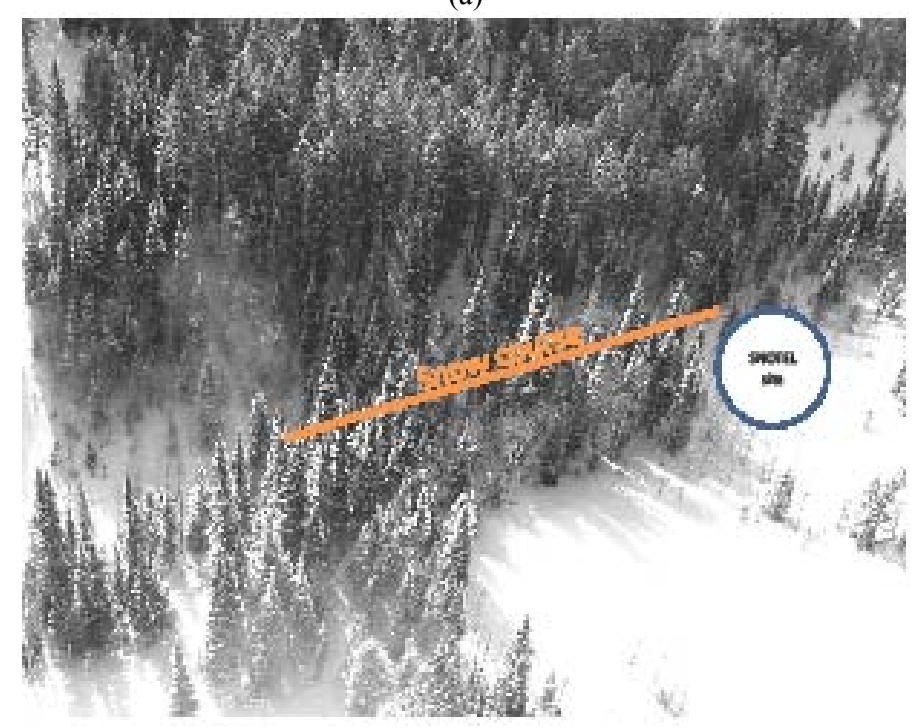

(b)

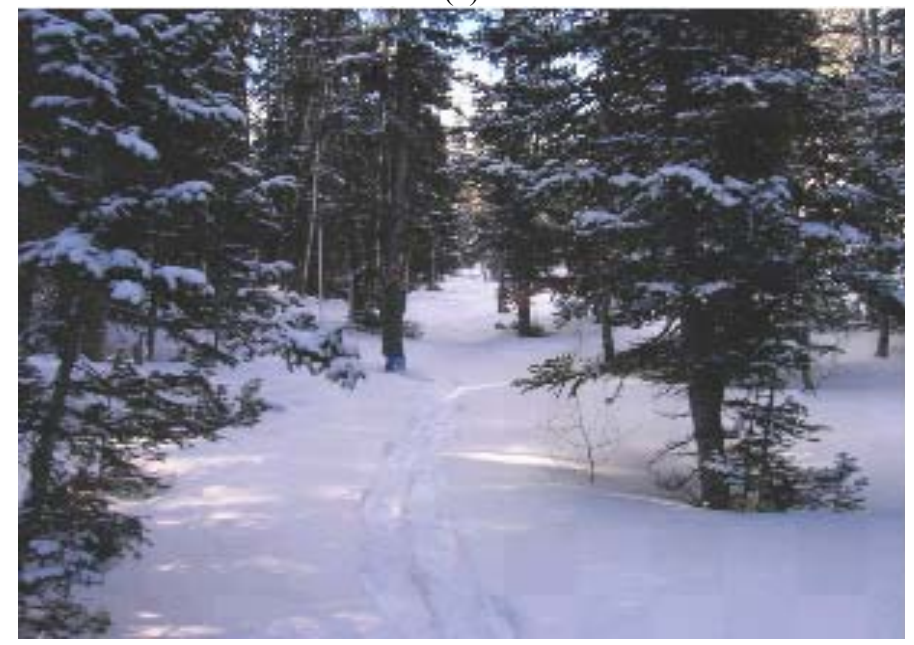

(c)

Fig. 5 Garden City Summit in 1936 (a) and 2005 (b and c). Historical photo from [59], recent photos by authors. 


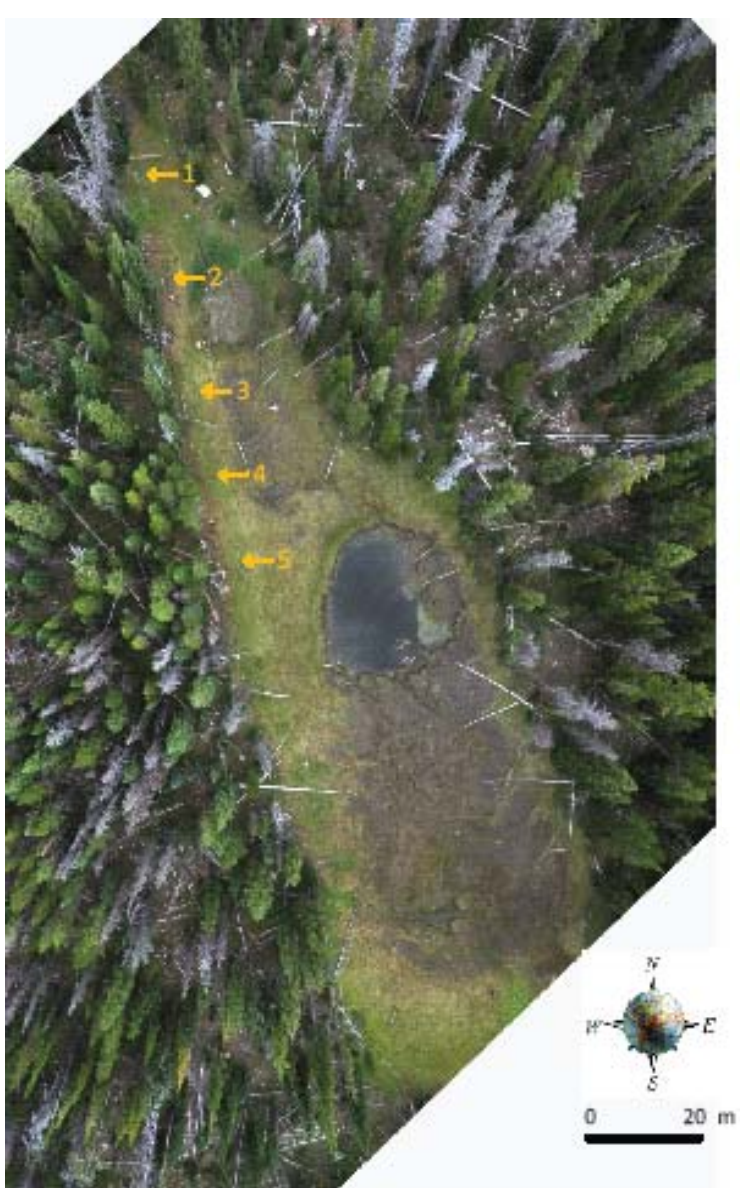

(a)

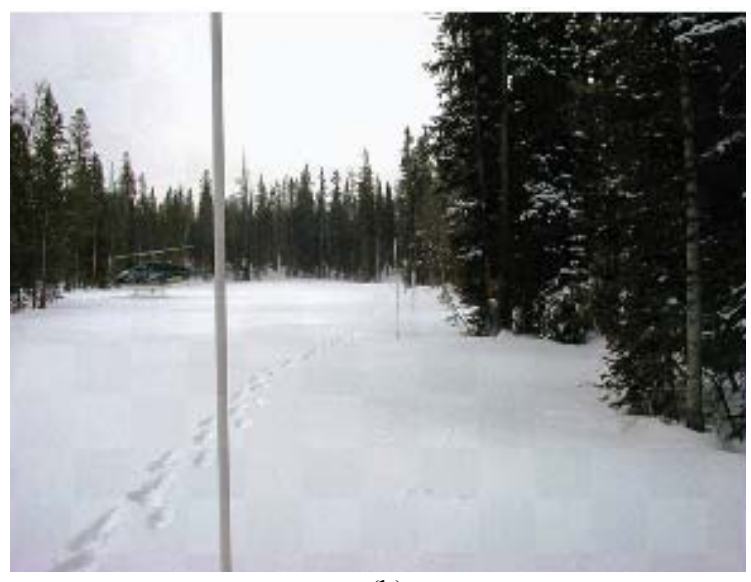

(b)

Fig. 6 Trial Lake snow course, taken using remotely-controlled helicopter with downward-looking camera, 2012 (a) and at ground level (b). Snow course marker poles in (a) are indicated as numbered.

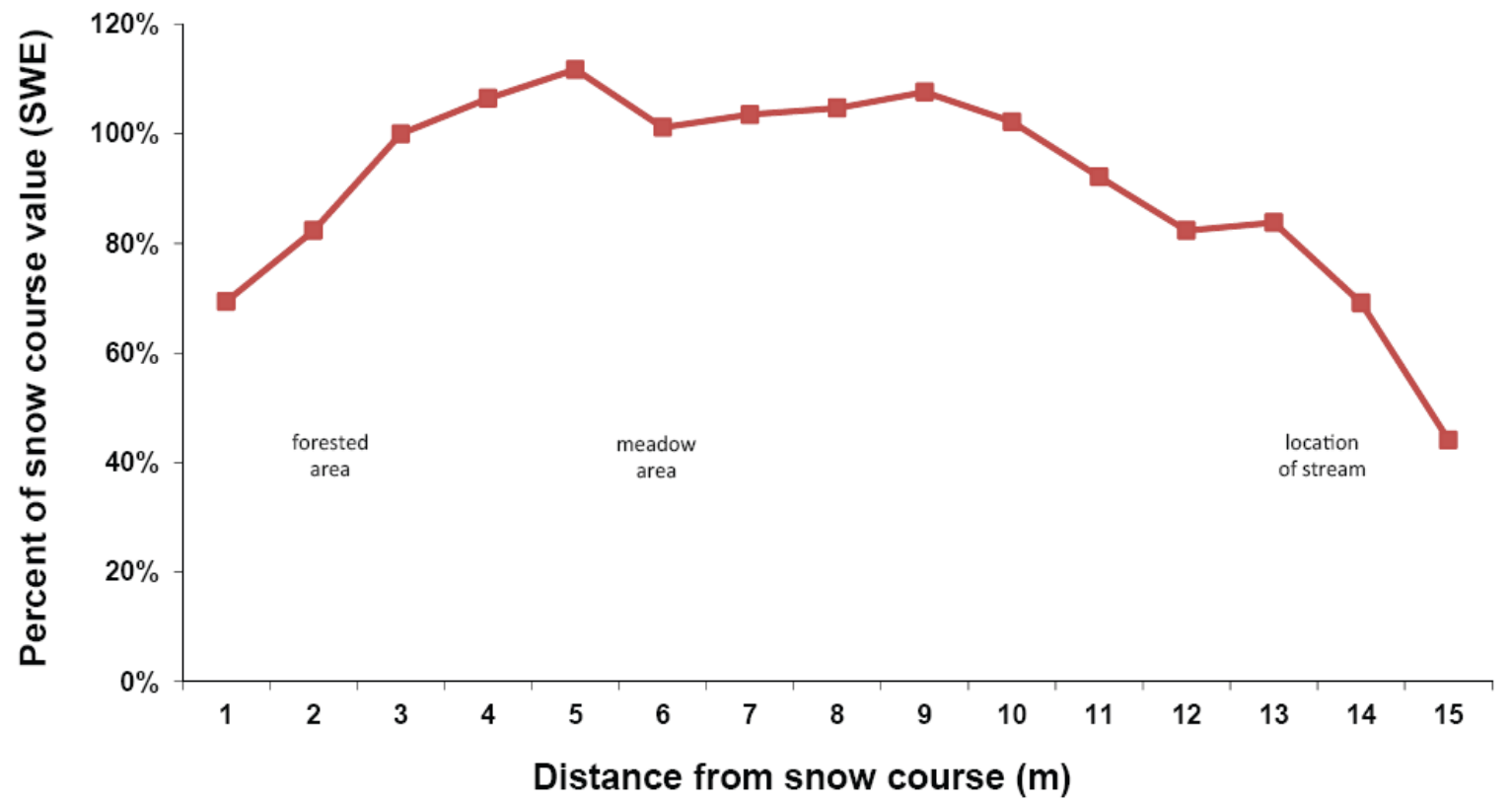

Fig. 7 Trial Lake SWE measurements taken perpendicular to the snow course, expressed as a percentage of the snow course value. The distance location " 3 " corresponds with the snow course location, and positive values are towards the open meadow. See text for details. 


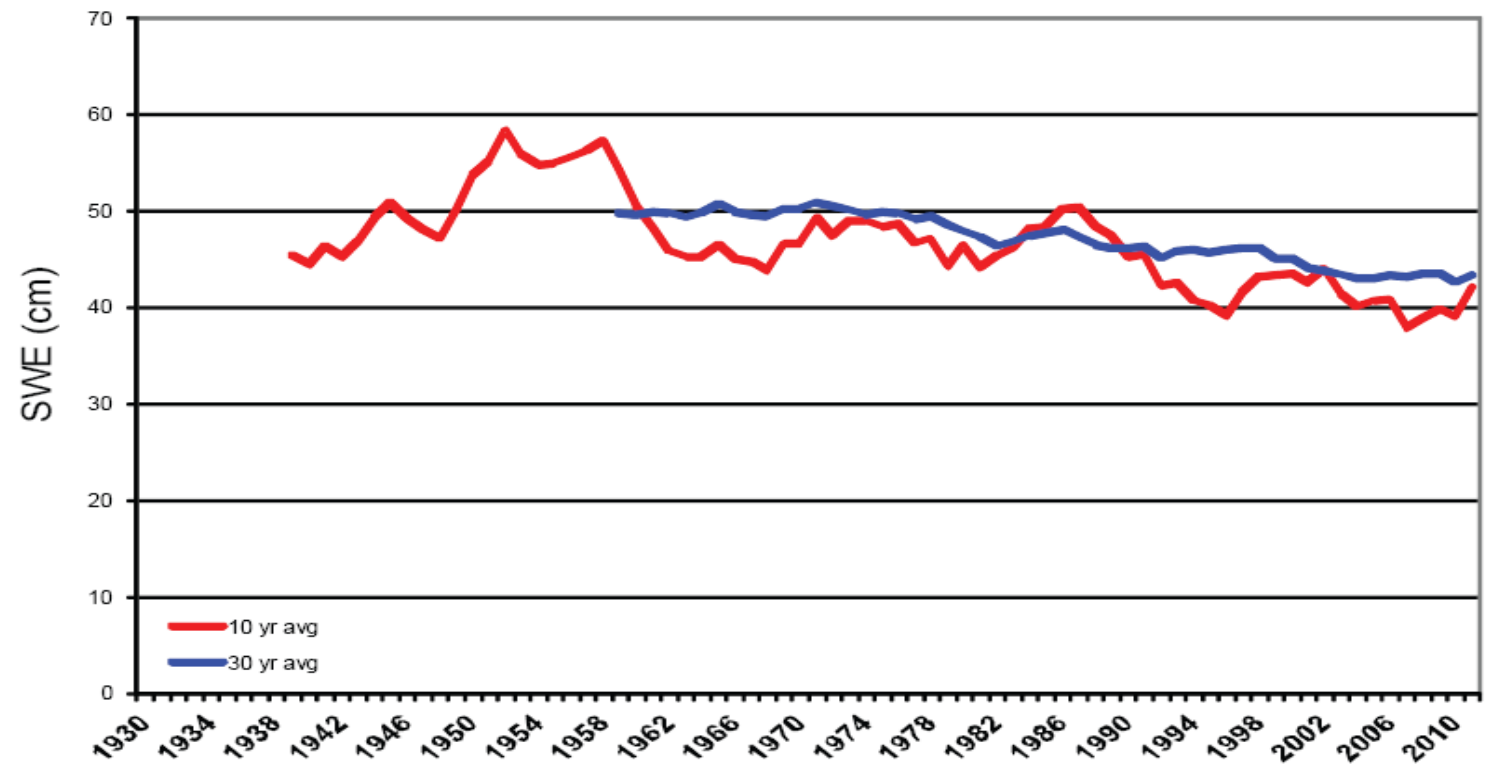

Fig. 8 Redden Mine, 10 and 30 year moving averages, April 1 SWE.

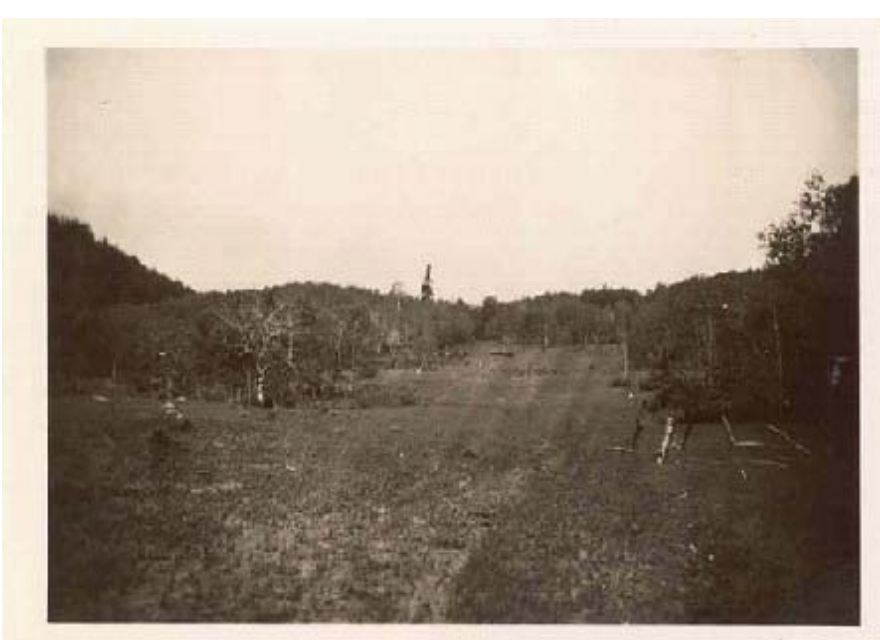

(a)

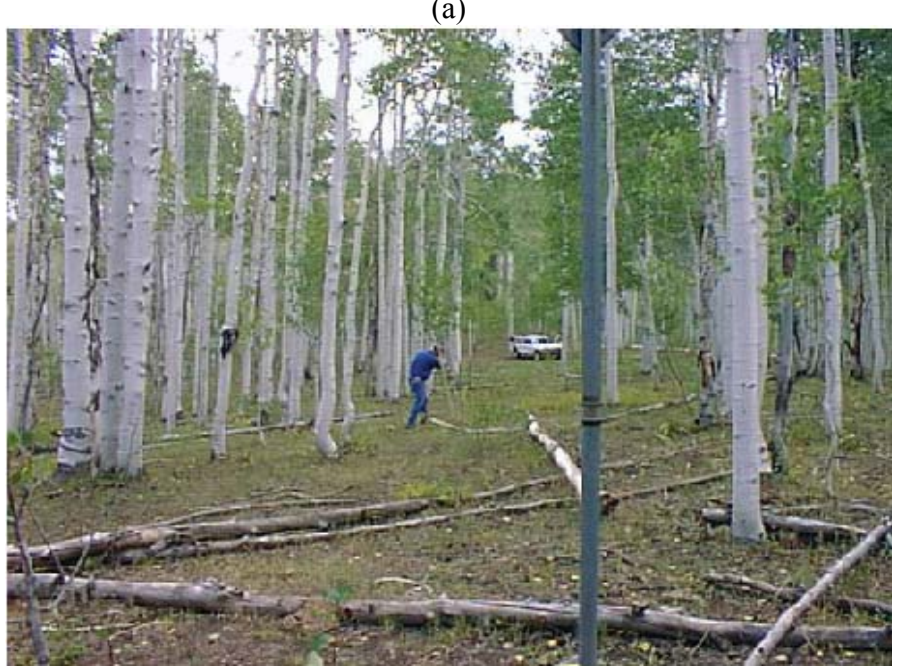

(b)

Fig. 9 Redden Mine in 1936 (a) and 2012 (b). Historical photo from [59], recent photo by authors. 


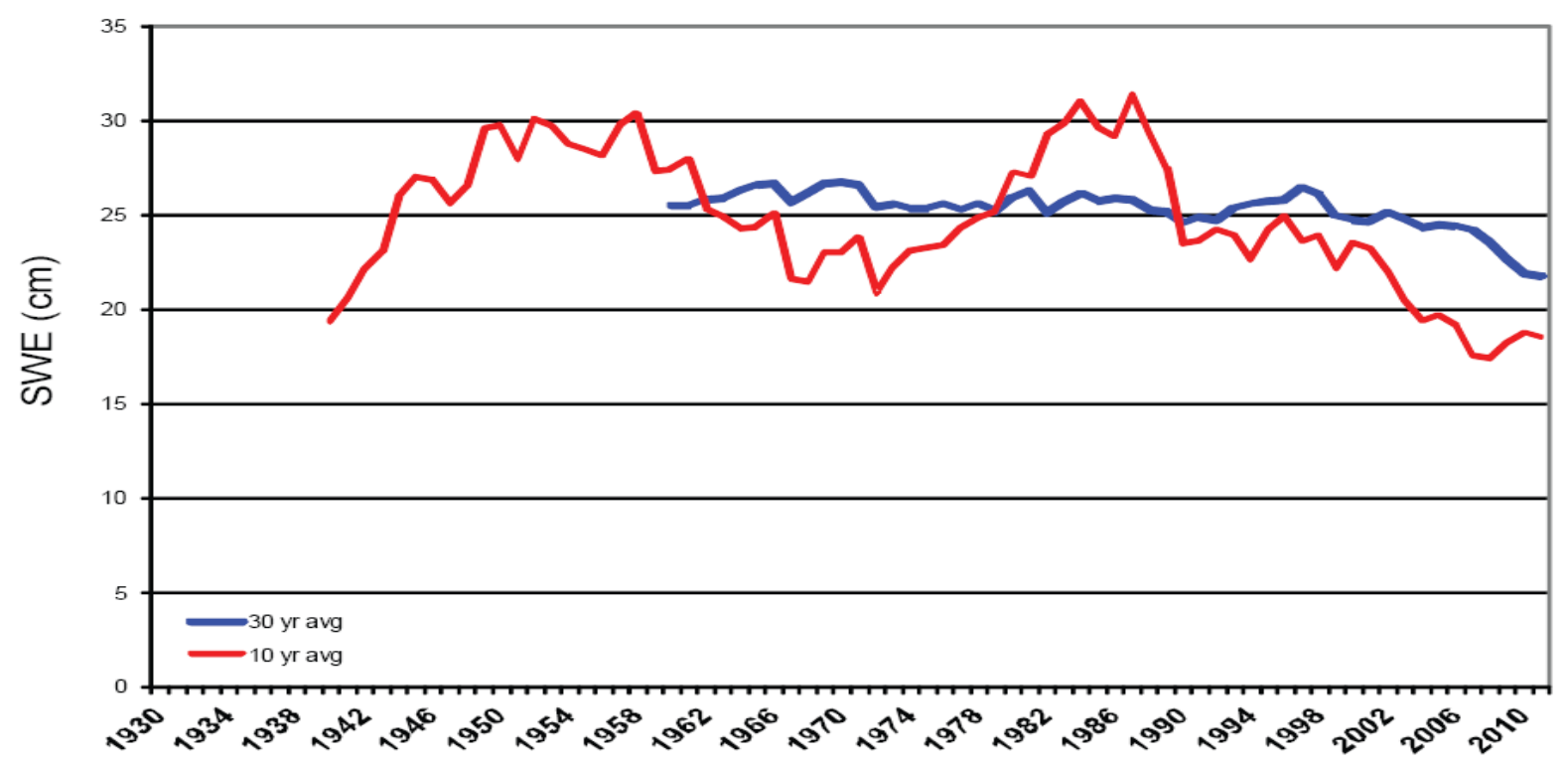

Fig. 10 Lasal Mt Lower, 10 and 30 year moving averages, April 1 SWE.

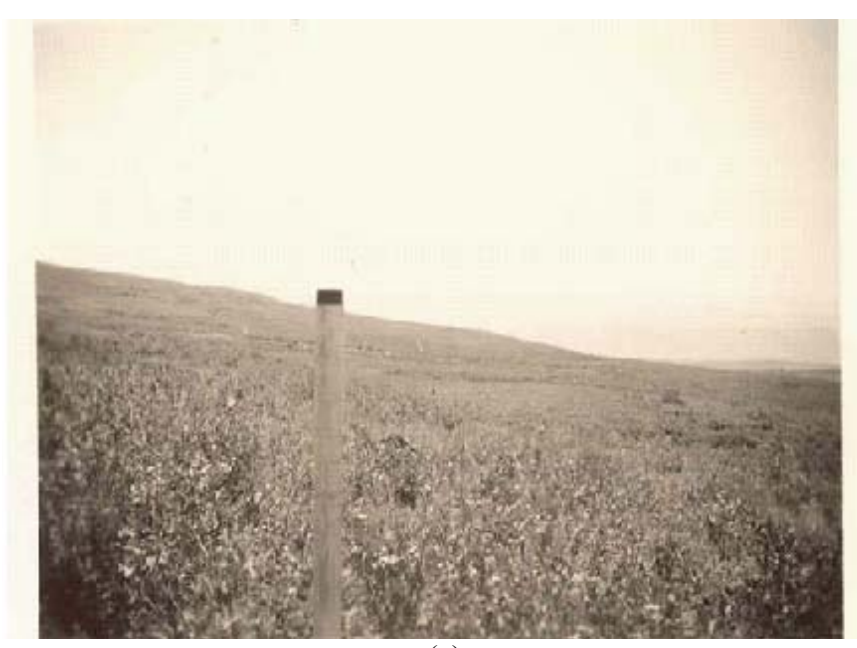

(a)

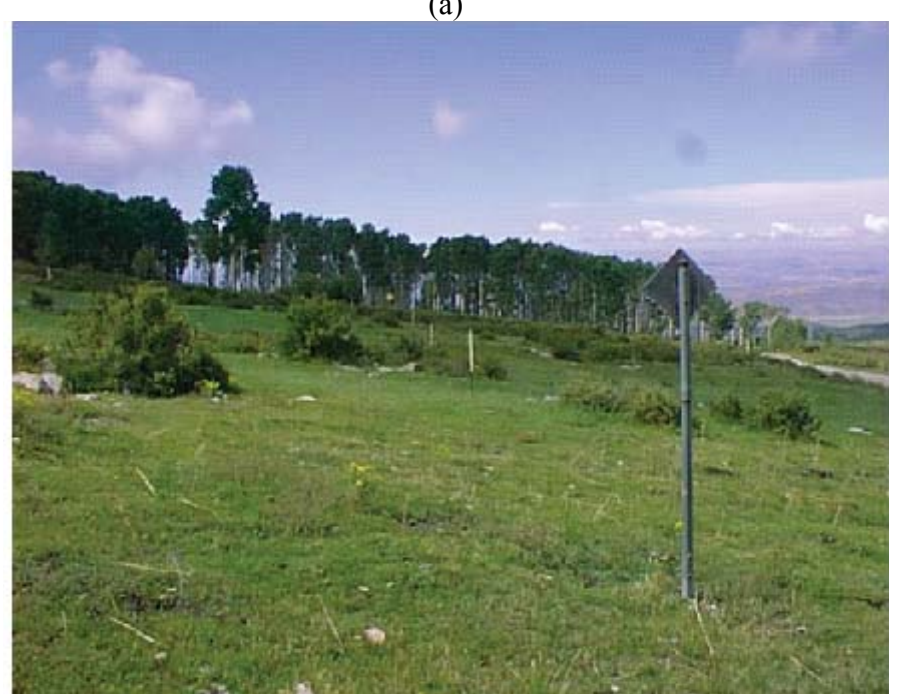

(b)

Fig. 11 Lasal Mt Lower in 1936 (a) and 2012 (b). Historical photo from Ref. [59], recent photo by authors. 


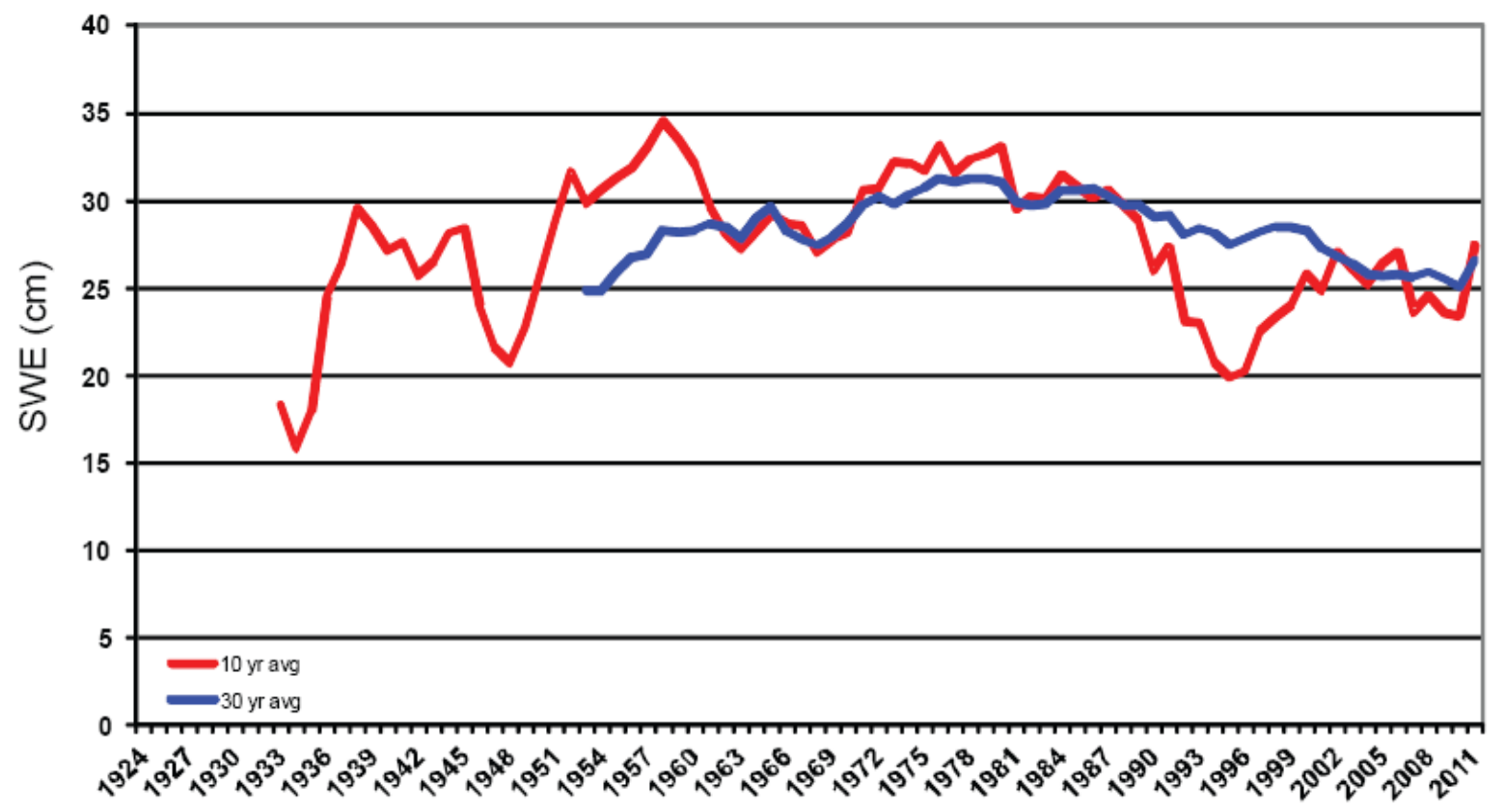

Fig. 12 Tony Grove RS, 10 and 30 year moving averages, April 1 SWE.

of the woody shrubs (this is a fairly low accumulation site overall) now sits upon grasses that provide little to no shelter from the wind (similar to Ref. [63]). Similar to SWE decreases with increasing forest cover, shifts in vegetation to conditions that inhibit snow accumulation or promote erosion of the snowpack are bound to have a pronounced effect on measured SWE.

In addition to vegetation changes, other site-level factors impacted snow accumulation and SWE at the 15 snow course sites. The Tony Grove RS snow course, at $1905 \mathrm{~m}$ elevation and a southerly aspect, has one of the longest records in the state. April 1 SWE values show a $10 \%$ decline in recent years as compared with the 1941-1970 period (Table 2 and Fig. 12). Of all the snow courses described in this study, this site has the lowest elevation, and its southerly aspect would likely be most susceptible to warmer temperatures. However, two of the sample points in the snow course (numbers 4 and 5) have been impacted by the addition of an asphalt road between them, thereby raising the surface elevation by $\sim 0.3 \mathrm{~m}$, altering the fetch characteristics, and decreasing the surface albedo for the surrounding area. Moreover, during winter months the road is now used for recreation (both ski and snowmobile) (Fig. 13).

At the Mill D South snow course there has been a slight decline (10\%) in SWE (Table 2 and Figure 14a). Although vegetation has increased slightly at this site, it has not increased sufficiently to adversely impact snow accumulation. However, in 1997 a large, two story home was constructed on the upwind, west end of this snow course within a few meters of the sample locations (Fig. 15). This structure has likely impacted snow distribution patterns and contributed to the decline in observed SWE. The Mill D South site is only $4.8 \mathrm{~km}$ from the Parley's Canyon Summit snow course (ID 11J15), and both share the same elevation and aspect. There has been no detectable decline in SWE at the Parley's Canyon Summit site (Fig. 14b), and the timing of the decline in SWE at Mill D South is coincident with the construction of the house, strongly suggesting that the decrease at this site is due to local, not regional, factors.

At the Burts Miller Ranch snow course, there has been a decline in SWE of around 25\%. Unlike the gradual declines described where vegetation increases have been observed (noted above), a physical change in the late 1970s lowered the April 1 SWE accumulation 


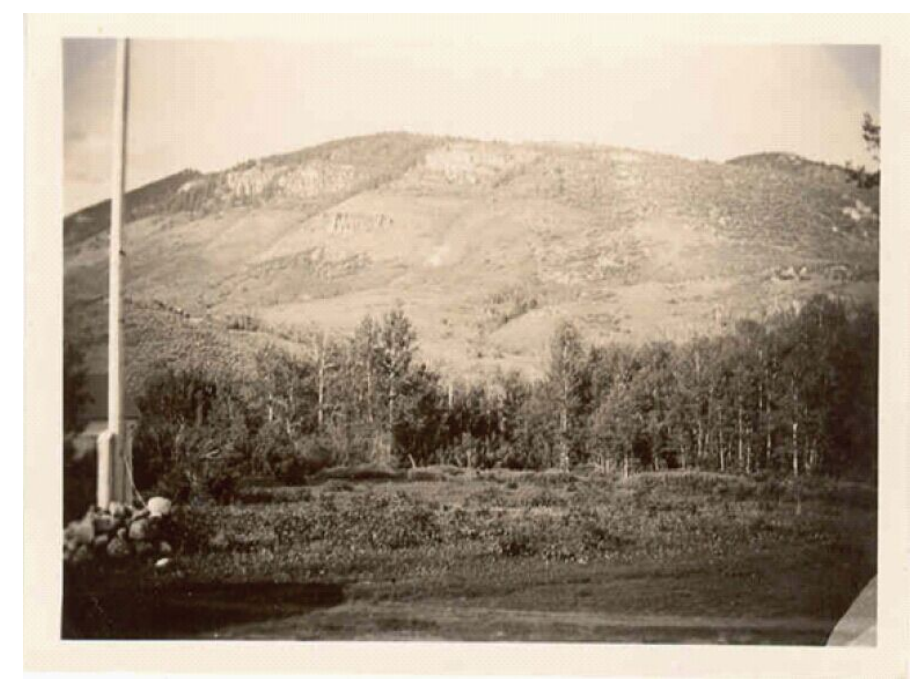

(a)

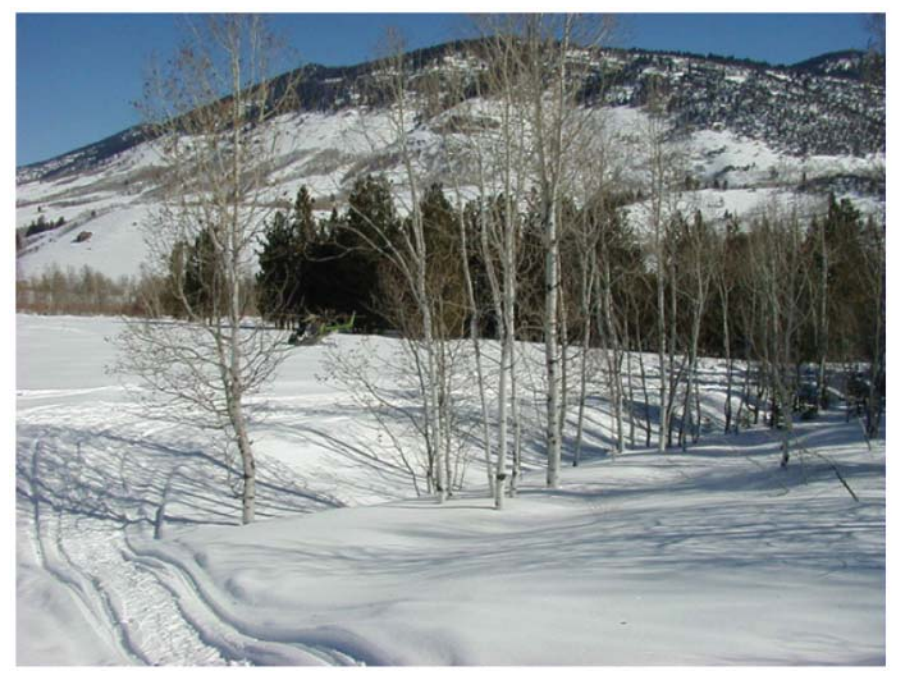

(b)

Fig. 13 Tony Grove RS in 1936 (a) and 2012 (b). Historical photo from [59], recent photo by authors.

rather abruptly (Fig. 16). Aerial photographs of this site show that there were sub irrigation impacts from a small nearby reservoir and ditch that were installed just prior to the decline in SWE. Current photos of the site show standing water on the snow course with intact snowpack only a short distance away (outside the influence of the reservoir and ditch) (Fig. 17). Since the installation of these irrigation features, SWE values have re-stabilized at a lower level (Fig. 16, right side of diagram).

In contrast, the remaining sites (Bryce Canyon, Fish Lake, GBRC Meadows, Gooseberry RS, Hobble Creek Summit, Huntington Horseshoe, and Panguitch
Lake) of the 15 longest-term snow courses in Utah all have essentially steady SWE over time (Fig. 18), and none have significant vegetation or physical changes (see Fig. 19, for example), though almost all sites have had some increase in vegetation (forest) coverage over time. These sites are distributed widely across the state and do not correspond with any particular elevation or aspect.

\section{Discussion and Conclusions}

Other things being equal, a warming climate should impact lower elevation sites first because of the increased proximity to freezing thresholds in typical 

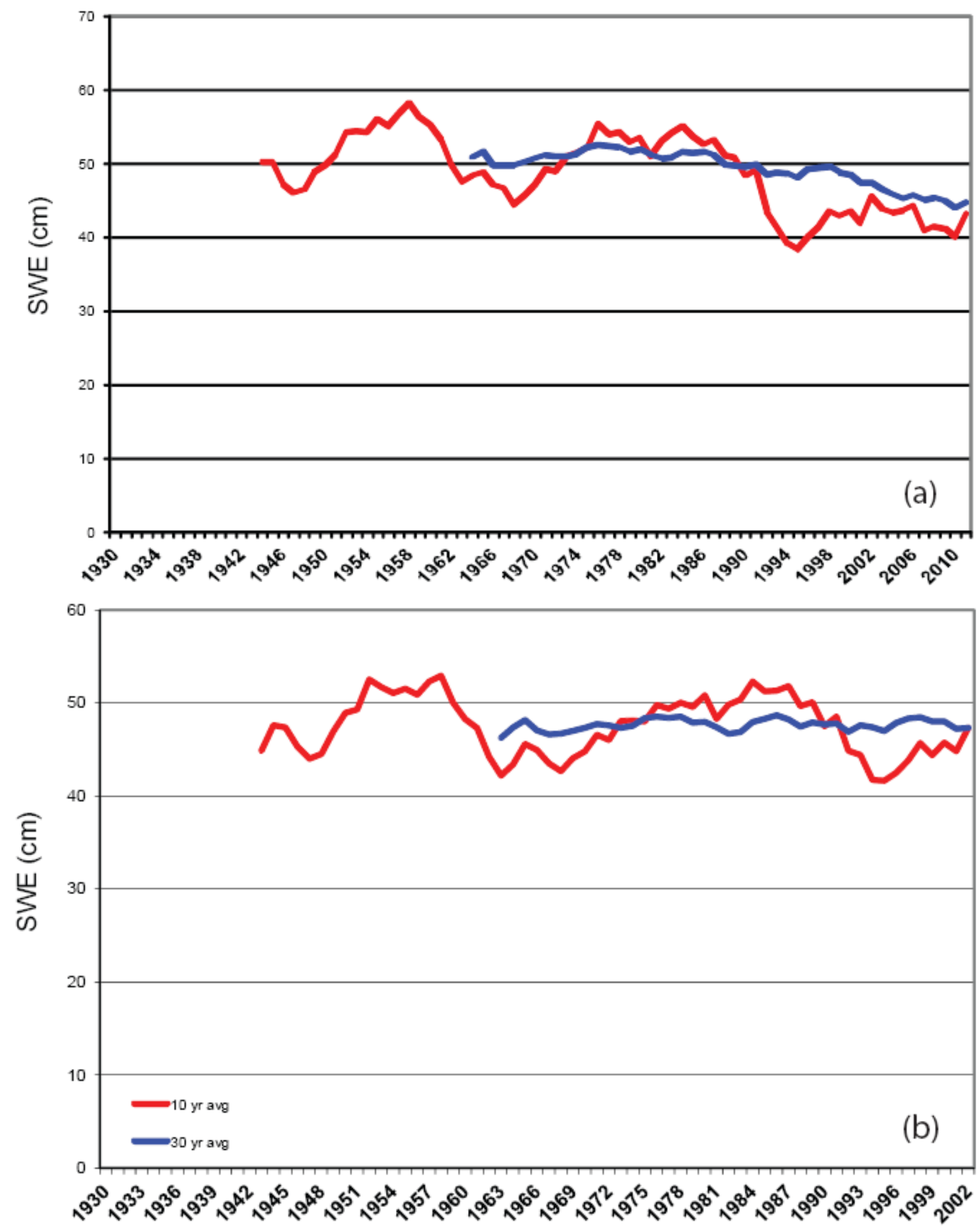

Fig. 14 Mill D (a) and Parley's Summit (b), 10 and 30 year moving averages, April 1 SWE. Note that the Parley's Summit snow course was discontinued in 2000. 


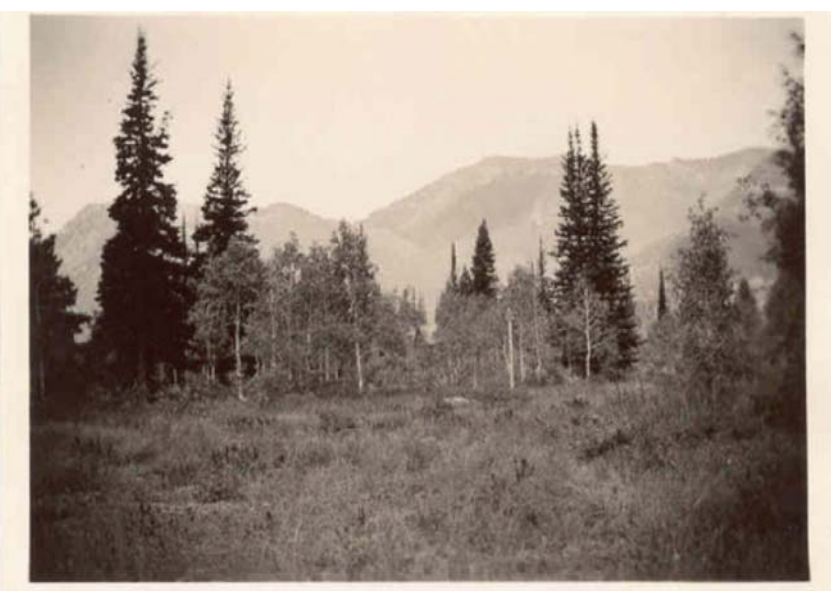

(a)

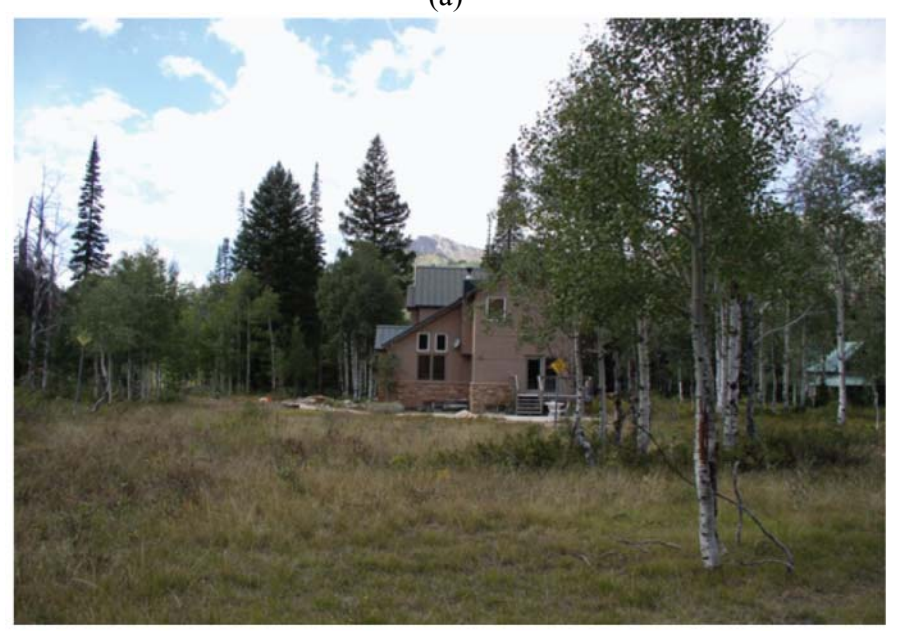

(b)

Fig. 15 Mill D in 1936 (a) and 2012 (b). Note the yellow snow course endpoint in front of the house in (b). Historical photo from Ref. [59], recent photo by authors.

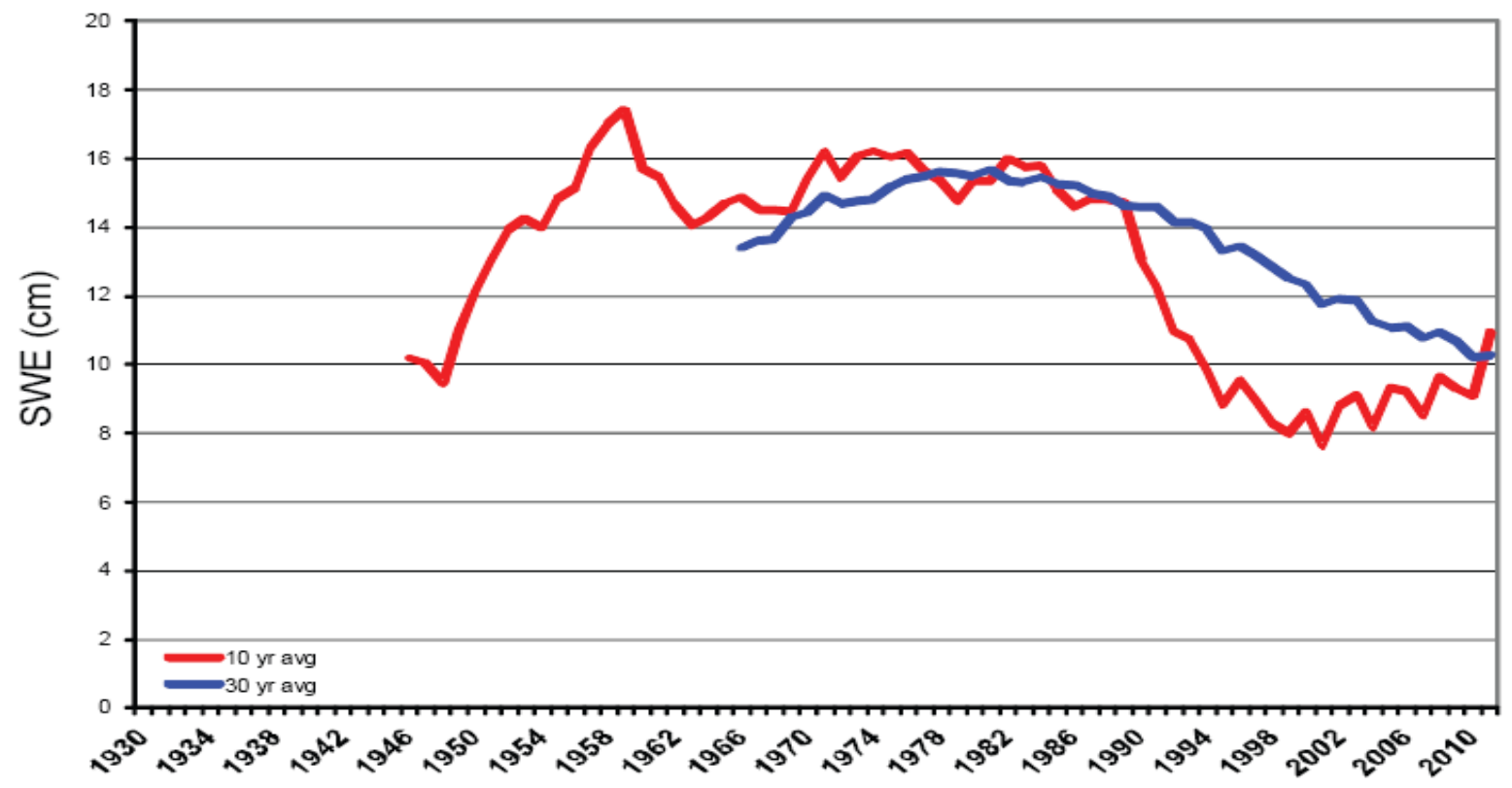

Fig. 16 Burts Miller Ranch,10 and 30 year moving averages, April 1 SWE. 


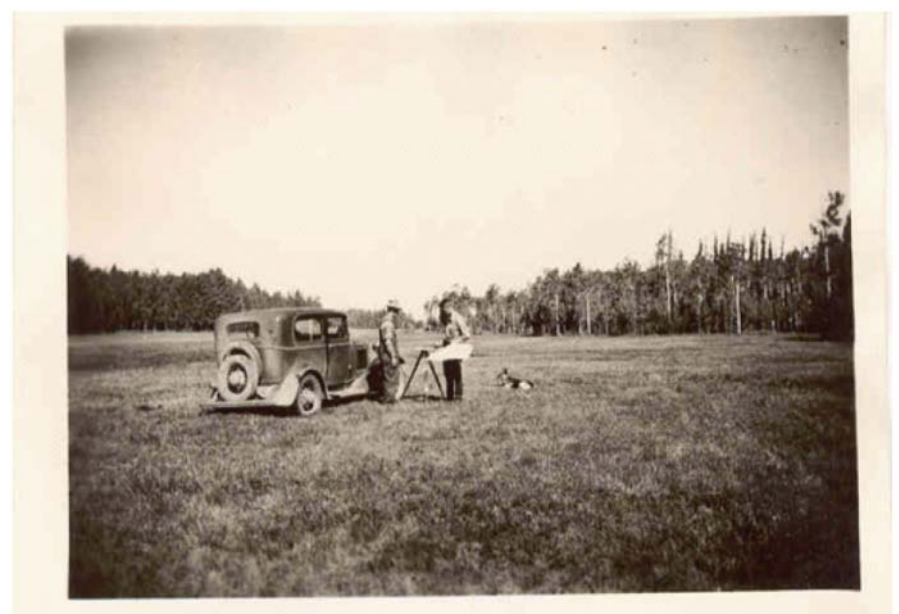

(a)

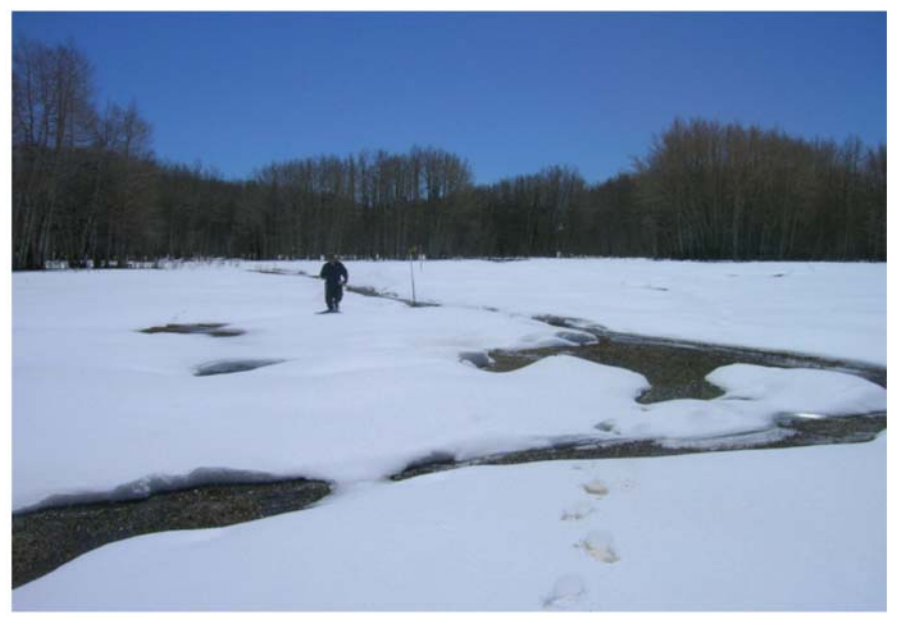

(b)

Fig. 17 Burts Miller Ranch in 1936 (a) and 2012 (b). Historical photo from Ref. [59], recent photo by authors.

water years. A limitation of this analysis is its small sample size, particularly in that it does not include sites below 1,900 meters in elevation. Differences in SWE accumulation in the intermountain West have been shown to increase strongly with elevation [64, 65, and numerous others]; reductions in SWE through ablation (particularly sublimation) are also elevation-dependent, though in the opposite direction: higher-elevation sites lose SWE more rapidly [6]. This latter effect does not likely impact our results as SWE losses typically occur after April 1 for the high elevation sites in this study. Several authors $[6,10,13$, 66] suggest that colder continental regions are less subject to climate variability than Pacific Northwest and Sierra Mountain regions, and that warming effects will not be uniformly distributed. Of the sites that have significant differences in SWE over the past two decades, two are in northern Utah, two in central Utah and one in southeast Utah. One would expect the three lower elevation and latitude sites (Bryce Canyon, Lasal Mt Lower, and Panguitch Lake) to be more susceptible to warming, yet only one has experienced significant decreases in SWE.

Geographic complexity in mountain terrain is understood to complicate signals in SWE and other snowpack data [6, 14, 49]. Moreover, results from [13] indicate that the ability to forecast warming and snowpack trends is a function of the kind of model used, number of parameters used in the modeling, the ability to run a physically-based model, and other 

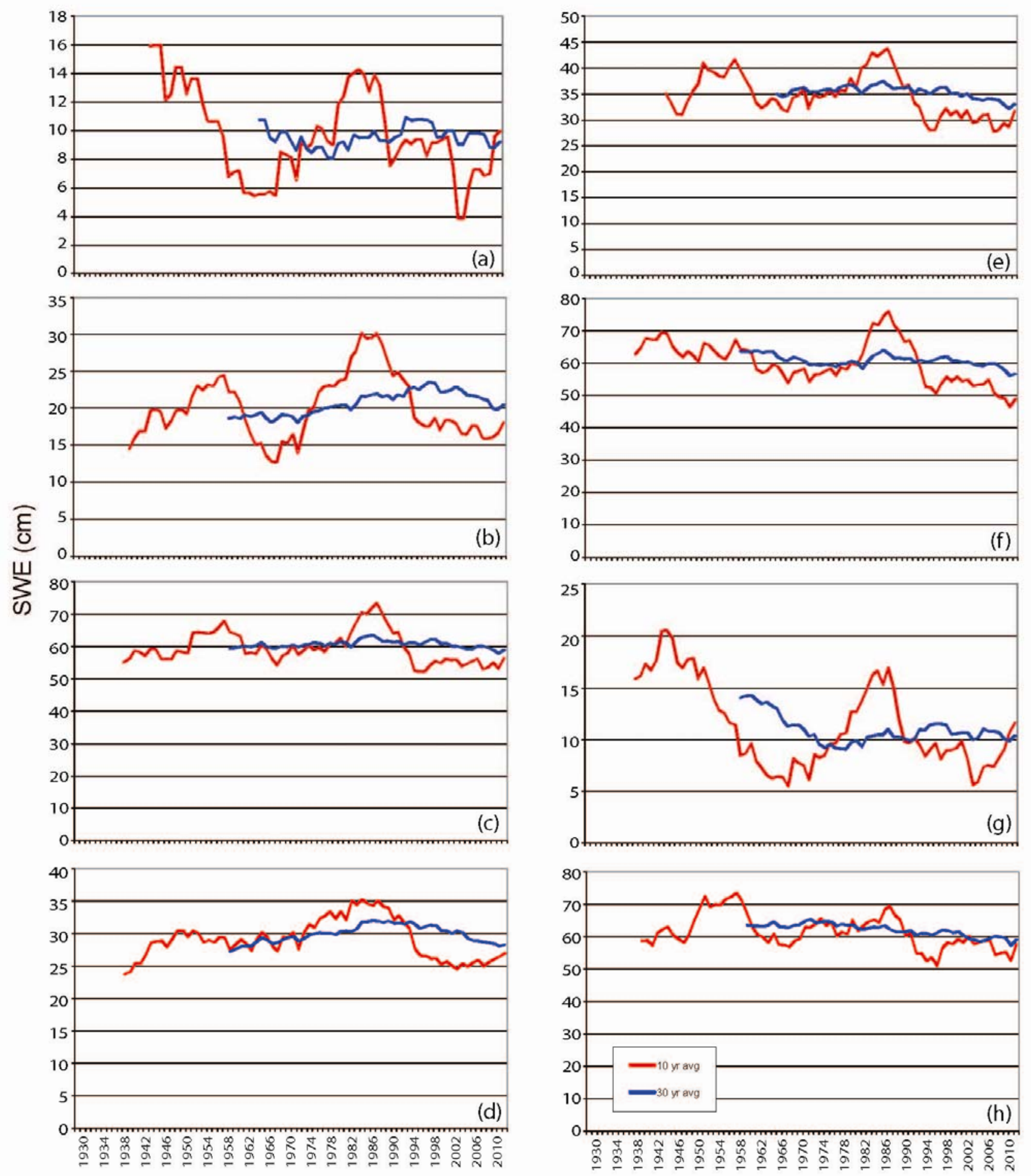

Fig. 1810 and 30 year moving averages, April 1 SWE, for Bryce Canyon (a), Fish Lake (b), GBRC Meadows (c), Gooseberry RS (d), Hobble Creek Summit (e), Huntington Horseshoe (f), Panguitch Lake (g), and Trial Lake (h) snow courses. 
Table 4 Reference snow courses in Utah that are best-suited for long-term climate studies. Site meta-information is available at $[60]$.

\begin{tabular}{|c|c|c|c|c|c|c|}
\hline Site & Elevation (m) & Latitude & Longitude & County & HUC & Install year \\
\hline Black's Fork Junction & 8,930 & 40.97 & -110.58 & Summit & 14040107 & 1961 \\
\hline Bryce Canyon & 8,000 & 37.62 & -112.17 & Garfield & 16030002 & 1935 \\
\hline Buck Pasture & 9,700 & 40.85 & -110.67 & Summit & 14040107 & 1963 \\
\hline Chalk Creek \#3 & 7,500 & 40.92 & -111.10 & Summit & 16020101 & 1952 \\
\hline East Fork-Black's Fork G.S. & 9,340 & 40.88 & -110.53 & Summit & 14040107 & 1961 \\
\hline Fish Lake & 8,700 & 38.50 & -111.77 & Sevier & 14070003 & 1931 \\
\hline G.B.R.C. Meadows & 10,000 & 39.30 & -111.45 & Sanpete & 16030004 & 1930 \\
\hline Gooseberry R.S. & 8,400 & 38.78 & -111.68 & Sevier & 16030003 & 1930 \\
\hline Henry's Fork & 10,000 & 40.88 & -110.37 & Summit & 14040106 & 1963 \\
\hline Huntington-Horseshoe & 9,800 & 39.62 & -111.30 & Sanpete & 14060009 & 1930 \\
\hline Johnson Valley & 8,850 & 38.62 & -111.48 & Sevier & 14070003 & 1955 \\
\hline Lakefork Mountain \#3 & 8,400 & 40.55 & -110.35 & Duchesne & 14060003 & 1953 \\
\hline Mt. Baldy R.S. & 9,500 & 39.13 & -111.50 & Sanpete & 16030004 & 1951 \\
\hline Parley's Canyon Summit & 7,500 & 40.77 & -111.62 & Salt Lake & 16020102 & 1934 \\
\hline Spirit Lake & 10,300 & 40.83 & -110.00 & Daggett & 14040106 & 1963 \\
\hline Squaw Springs & 9,300 & 38.48 & -112.00 & Piute & 16030002 & 1954 \\
\hline Susc Ranch & 8,200 & 37.60 & -112.92 & Iron & 16030006 & 1966 \\
\hline Tall Poles & 8,800 & 37.72 & -112.83 & Iron & 16030006 & 1965 \\
\hline Thistle Flat & 8,760 & 39.23 & -111.52 & Sanpete & 16030004 & 1956 \\
\hline Upper Joe's Valley & 8,900 & 39.42 & -111.25 & Emery & 14060009 & 1956 \\
\hline White River \#3 & 7,400 & 39.93 & -111.03 & Wasatch & 14060007 & 1955 \\
\hline Wrigley Creek & 9,000 & 39.13 & -111.35 & Sanpete & 14060009 & 1955 \\
\hline
\end{tabular}

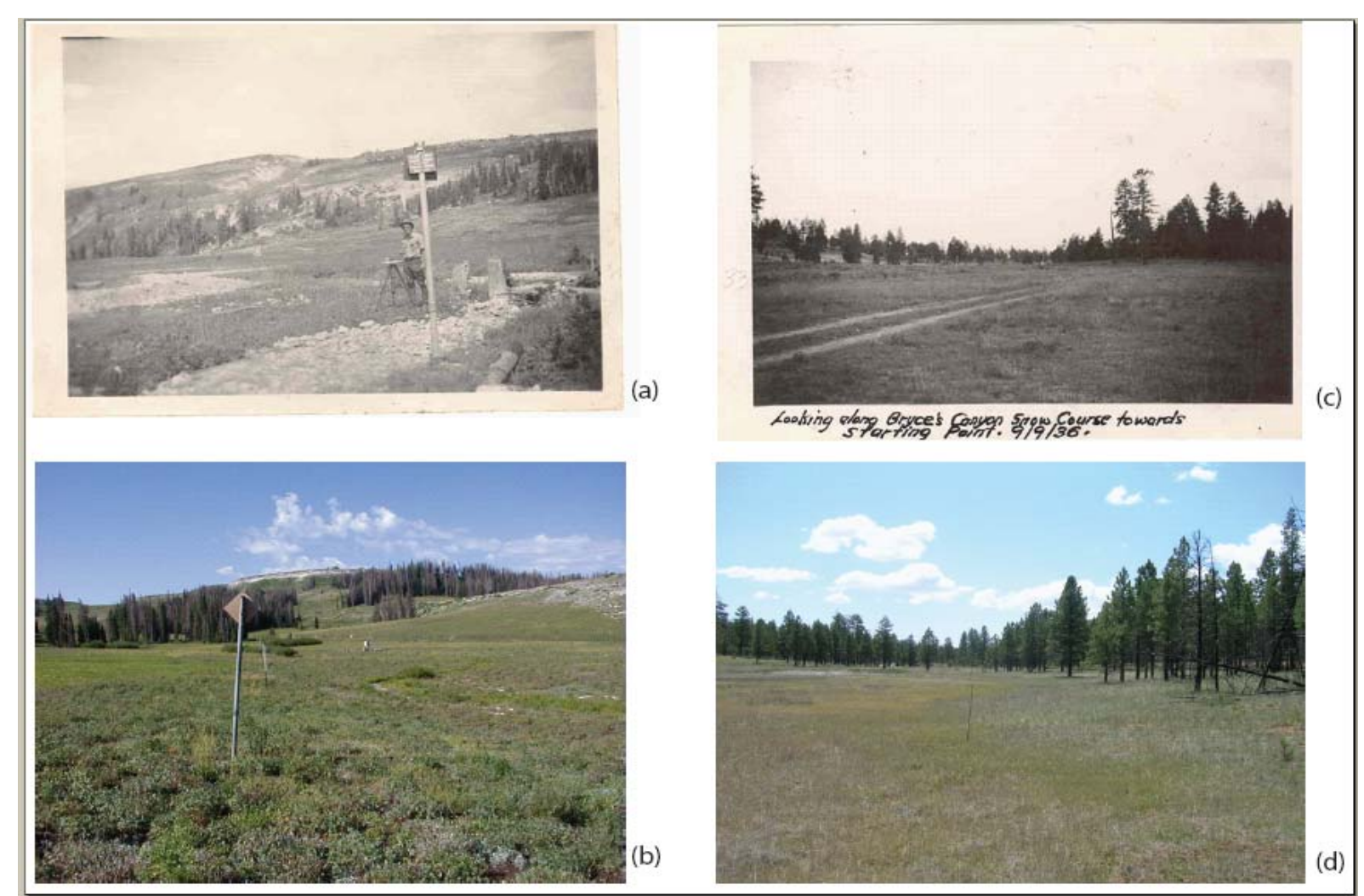

Fig. 19 GBRC Meadows in 1936 (a) and 2012 (b), and Bryce Canyon in 1936 (c) and 2012 (d). Historical photos from Ref. [59], recent photos by authors. 
factors. Others $[67,68]$ show that oscillating patterns, such as connections between April 1 SWE and atmospheric and oceanic circulation patterns, provide a very strong influence on SWE variability; the magnitude of which may exceed both climate change or vegetation encroachment effects. Even more uncertainty in SWE trends over time comes from other studies that either do not substantiate decreases in SWE for the Utah region [51] or suggest that SWE has actually increased or may increase in the future [17]. Harpold et al. [6] show that the duration of snow cover has decreased for many locations in the intermountain U.S. West over the last two decades and recommend using the maximum SWE (as opposed to the April 1 value) to assess changes over time.

Over longer timescales many interrelated factors may produce fluctuations in SWE. Using a combination of snow course and tree ring data, Timilsena and Piechota [69] reconstructed SWE over the last $\sim 500$ years, linking variations in SWE to drought cycles, among other factors. They concluded that, for northeastern Utah, droughts have typically lasted for about 5 years and that the 1700 s were probably the driest period within that time frame. For the observation period provided from the 15 oldest snow courses in Utah, there is no question that the 1990s and 2000s have been drier than any period since the 1930s. Yet when we compare the most recent 10 year period (2002-2011) to the period of record mean there are no sites (of these 15) that have significantly different SWE. These results are consistent with those of [66] for the Colorado River Basin as a whole.

Our goal herein has not been to attempt to disprove any one particular influence on SWE, but rather to reinforce that there are many factors that have impacted the observed SWE values at Utah snow courses, and that local site factors play an important role. Based on the comparison of decadal means and 30 year average SWE per site (Tables 2 and 3), every site that had statistically significant declines in snowpack also had vegetative or other substantial site physical changes. Of the remaining sites, Huntington Horseshoe and Gooseberry RS are both high elevation locations and ought to be less likely to be influenced by the magnitude of temperature increases reported in the literature. While we have omitted discussion of other factors that contribute to variability in observed SWE over time (such as changes in the types of pillows used at SNOTEL sites, see Ref. [70] for reports on these and related topics), we hope to underscore from the site examinations given above that researchers should take care to evaluate the influence of local site factors on long term SWE data. Ideally, this examination would include communication with NRCS snow survey staff (see contact information provided at Ref. [71]) or other relevant field personnel to determine if local factors exist that may have compromised a given site's data integrity, and if so, to what extent. Additionally, we provide here a list of 22 reference sites that we feel would be best-suited for long-term climate studies (Table 4), similar to the U.S. Geological Survey's "GAGES-II: Geospatial Attributes of Gages for Evaluating Streamflow" reference information developed by Falcone [72]. Our list was generated from frequent site visits and from our expertise regarding the Utah snow courses. Included are sites where vegetation encroachment, geomorphic changes, and human development have (apparently) played a minimal role in the integrity of the snow course measurement locations. Other, more widespread, factors may still need to be accounted for, however, such as cloud seeding or variable dust accumulation. In addition, while we have excluded SNOTEL sites from Table 4 (the earliest SNOTELs were installed in the late 1970s, and many were installed much more recently than that), it should be noted that most SNOTEL sites in Utah are located at or near historic snow courses and can be used to extend the long-term analysis. In these situations, snow measurements are obtained at both the snow course and SNOTEL 
sample points to enable correlations to be made; this sampling protocol is maintained for the first $\sim 5$ years of a SNOTEL site's existence before the snow course is discontinued. In addition, site factors affecting both the snow course and SNOTEL locations must be considered in order for the correlation between the two to be robust. We are not currently able to compare decadal trends in SWE or snow depth at co-located SNOTEL and snow course measurement sites-as suggested by others, such as examining the ratio of snow course to SNOTEL SWE over long time periods [73] — due to the SNOTELs' fairly short period of record; this avenue of research, combined with satellite imagery to characterize changes in vegetation cover over time at each of these sites, should be pursued in the future.

The magnitude of changes in SWE at the 15 snow courses investigated herein were quantified where possible by measuring SWE decreases towards vegetated areas (perpendicular from the snow course) and were found, in several cases, to approximately match the observed loss at the site. Our study supports other work $[26,32]$ that identify the influence of vegetation changes on observed SWE. About $50 \%$ of the sites examined in this study were found to be compromised by vegetation growth or other factors. As vegetation growth in Utah has generally been much slower than in states with greater annual precipitation (e.g. the Pacific Northwest), our results imply that vegetation biases on observed SWE may be even greater in other areas. This suggests that the growth of the forest canopy is an issue that should be quantified for multiple regions and may influence SWE accumulation as much as, or more than, broad-scale climatic factors. It is therefore possible that research that has documented declines in SWE across the western US and attributed the declines mainly to warming temperature without sufficiently accounting for site-level changes [2, 74] have overestimated the impacts. Using data from non-compromised sites through 2011 shows that Utah snowpacks have declined about 3\% compared to the period of record average. Because each site is impacted by vegetation change differently, a process needs to be developed to quantify individual site vegetation bias on SWE, such as where both impacted and un-impacted sites exist within the same watershed and have sufficiently long periods of record. More broadly, using only data from non-compromised sites would be a more appropriate measure of larger scale phenomena such as climate change as it would substantially reduce the non-climate-related, local bias in the dataset.

Although patterns in snowpack data consistent with what would be expected due to temperature increases - such as greater declines at lower elevations and latitudes [14, 75]-were not identified, snow water equivalent decreased at sites with significant increases in vegetation coverage. These results are consistent with others researchers [25] who have identified substantial reductions in SWE in vegetated areas that must be accounted for in water resources investigations.

\section{References}

[1] Hamlet, A. F., Mote, P. W., Clark, M. P., and Lettenmaier, D. P. 2005. "Effects of Temperature and Precipitation Variability on Snowpack Trends in the Western United States.” Journal of Climate 18: 4545-61.

[2] Mote, P. W., Hamlet, A. F., Clark, M. P., and Lettenmaier, D. P. 2005. "Declining Mountain Snowpack in Western North America." Bulletin American Meteorological Society 86 (1): 39-49.

[3] Barnett, T. P., Pierce, D. W., Hidalgo, H. G, Bonfils, C., Santer, B. D., Das, T., Bala, G., Wood, A. W., Nozawa, T., Mirin, A. A., Cayan, D. R, and Dettinger, M. D. 2008. "Human-Induced Changes in the Hydrology of the Western United States." Science 319: 1080-83.

[4] Kalra, A., Piechota, T. C., Davies, R., and Tootle, G. A. 2008. "Changes in U.S. StreamLow and Western U.S. Snowpack." Journal of Hydrological Engineering 13 (3): 156-63.

[5] Miller, W. P., and Piechota, T. C. 2011. "Trends in Western U.S. Snowpack and Related Upper Colorado River Basin StreamFlow." Journal of the American Water Resources Association 47 (6): 1197-210. 
[6] Harpold, A., Brooks, P., Rajagopal, S., Heidbuchel, I., Jardine, A., and Stielstra, C. 2012. "Changes in Snowpack Accumulation and Ablation in the Intermountain West." Water Resources Research 48: W11501.

[7] Bedford, D., and Douglass, A. 2008. Changing Properties of Snowpack in the Great Salt Lake basin, Western United States, from a 26-year SNOTEL Record. The Professional Geographer 60 (3): 374-86.

[8] Jones, L. P., and Horel, J. D. 2009. "Assessing the Sensitivity of Wasatch Mountain Snowfall to Temperature Variations." In Proceedings of the Western Snow Conference, 47-55.

[9] Gillies, R. R., Wang, S. Y., and Booth, M. R. 2012. "Observational and Synoptic Analyses of the Winter Precipitation Regime Change over Utah." Journal of Climate 25: 4679-98.

[10] Serreze, M. C., Clark, M. P., Armstrong, R. L., McGinnis, D. A., and Pulwarty, R. S. 1999. "Characteristics of the Western United States Snowpack from Snowpack Telemetry (SNOTEL) Data." Water Resources Research 35 (7): 2145-60.

[11] Knowles, N., Dettinger, M. D., and Cayan, D. R. 2006. "Trends in Snowfall Versus Rainfall in the Western United States." Journal of Climate 19: 4545-59.

[12] Bonfils, C., Santer, B. D., Pierce, D. W., Hidalgo, H. G., Bala, G., Das, T., Barnett, T. P., Cayan, D. R., Doutriaux, C., Wood, A. W, Mirin, A., and Nozawa, T. 2008. "Detection and Attribution of Temperature Changes in the Mountainous Western United States." Journal of Climate 21: 6404-24.

[13] Day, C. A. 2009. "Modeling Impacts of Climate Change on Snowmelt Runoff Generation and Stream Flow across Western US Mountain Basins: A Review of Techniques and Applications for Water Resource Management." Progressin Physical Geography 33 (5): 614-33.

[14] Stewart, I. T. 2009. "Changes in Snowpack and Snowmelt Runoff for Key Mountain Regions." Hydrological Processes 23: 78-94.

[15] Regonda, S. K., Rajagopalan, B., Clark, M., and Pitlick, J. 2005. "Seasonal Shifts in Hydro-Climatology over the Western United States." Journal of Climate 18: 372-84.

[16] Carroll, S. S., and Cressie, N. 1997. "Spatial Modeling of Snow Water Equivalent Using Covariances Estimated From Spatial and Geomorphic Attributes." Journal of Hydrology 190: 42-59.

[17] McGinnis, D. L. 1997. "Estimating Climate-Change Impacts on Colorado Plateau Snowpack Using Downscaling Methods.” The Professional Geographer 49 (1): $117-25$.

[18] Christensen, N. S., Wood, A. W., Voisin, N., Lettenmaier, D. P., and Palmer, R. N. 2004. "The Effects of Climate
Change on the Hydrology of Water Resources of the Colorado River Basin." Climatic Change 62: 337-63.

[19] Zhou, X., Xie, H., and Hendrickx, J. M. H. 2005. "Statistical Evaluation of Remotely Sensed Snow-Cover Products with Constraints from Stream Flow and SNOTEL Measurements." Remote Sensing of the Environment 94: 214-31.

[20] Lazar, B., and Williams, M. W. 2010. "Potential Impacts of Climate Change for U.S. Wasatch Range Ski Areas: Projections for Park City Mountain Resort in 2030, 2050, and 2075." In Proceedings of the International Snow Science Workshop, 436-43.

[21] Peacock, S. 2012. "Projected 21st Century Changes in Temperature, Precipitation and Snow Cover over North America in CCSM4." Journal of Climate 25: 4405-29.

[22] Molotch, N. P., and Bales, R. C. 2006. "SNOTEL Representativeness in the Rio Grande Headwaters on the Basis of Physiographic and Remotely Sensed Snow Cover Persistence." Hydrological Processes 20: 723-39.

[23] Julander, R. P. 2009. "Systematic Bias in Utah Snow Data." Geological Society of America, Abstracts with Programs 41 (7): 581.

[24] Pomeroy, J. W., Gray, D. M., Shook, K. R., Toth, B., Essery, L. H., Pietroniro, A., and Hedstrom, N. 1998. “An Evaluation of Snow Accumulation and Ablation Processes for Land Surface Modeling." Hydrological Processes 12: 2339-67.

[25] Storck, P., Lettenmaier, D. P., and Bolton, S. M. 2002. "Measurement of Snow Interception and Canopy Effects on Snow Accumulation and Melt in a Mountainous Maritime Climate, Oregon, United States." Water Resources Research 38 (11): 1223.

[26] Mahat, V., and Tarboton, D. G. 2010. "Modeling the Effect of Vegetation on the Accumulation and Melting of Snow." In Proceedings of the Western Snow Conference 71-82.

[27] Carroll, S. S, and Carroll, T. R. 1989. "Effect of Forest Biomass on Airborne Snow Water Equivalent Estimates Obtained by Measuring Terrestrial Gamma Radiation.” Remote Sensing of Environment 27: 313-20.

[28] Marsh, P. 1999. "Snow Cover Formation and Melt: Recent Advances and Future Prospects." Hydrological Processes 13: 2117-34.

[29] LaMalfa, E. M., and Ryle, R. 2008. "Differential Snowpack Accumulation and Water Dynamics in Aspen and Conifer Communities: Implications for Water Yield and Ecosystem Function.” Ecosystems 11: 569-81.

[30] Burke, A. R., and Kasahara, T. 2011. "Subsurface Lateral Flow Generation in Aspen and Conifer-Dominated Hillslopes of a First Order Catchment in Northern Utah.” Hydrological Processes 25: 1407-17.

[31] Natural Resources Conservation Service. 1972. National 
Engineering Handbook, Part 630. http://www.nrcs.usda.gov/wps/portal/nrcs/detailfull/natio $\mathrm{nal} /$ water/?cid=stelprdb1043063.

[32] Varhola, A., Coops, N. C., Weiler, M., and Moore, R. D. 2010. "Forest Canopy Effects on Snow Accumulation and Ablation: An Integrative Review of Empirical Results." Journal of Hydrology 392 (3): 219-33.

[33] Nolin, A. W., and Brown, A. 2008. "Assessing the Representativeness of the NRCS SNOTEL System at A Basin-Wide Scale." In Proceedings of the Western Snow Conference 127-30.

[34] Molotch, N. P., Fassnacht, S. R., Colee, M. T., Bardsley, T., and Bales, R. C. 2001. "A Comparison of Spatial Statistical Techniques for the Development of A Validation Dataset for Mesoscale Modeling of Snow Water Equivalence.” Eos Transactions 82 (47): F553.

[35] Hiemstra, C. A., Liston, G. E., and Reiners, W. A. 2006. "Observing, Modeling, and Validating Snow Redistribution by Wind in a Wyoming Upper Treeline Landscape.” Ecological Modeling 197: 35-51.

[36] Julander, R. P., and Bricco, M. 2006. "An Examination of External Influences Embedded in the Historical Snow Data of Utah." In Proceedings of the Western Snow Conference, 67-78.

[37] Bruintjes, R. 1999. "A Review of Cloud Seeding Experiments to Enhance Precipitation and Some New Prospects.” Bulletin American Meteorological Society 80 (5): 805-20.

[38] Stauffer, N. E. Jr. 2001. "Cloud Seeding - the Utah Experience." Journal of Weather Modification 23 (1): 63-9.

[39] Griffith, D. A., Solak, M. E., and Yorty, D. P. 2009. "30+ Winter Seasons of Operational Cloud Seeding in Utah." Journal of Weather Modification 41: 23-37.

[40] Borys, R. D., Lowenthal, D. H., Cohn, S. A., and Brown, W. O. J. 2003. "Mountaintop and Radar Measurements of Anthropogenic Aerosol Effects on Snow Growth and Snowfall Rate." Geophysical Research Letters 30 (10): 1538.

[41] Griffith, D. A., Solak, M. E., Yorty, D. P. 2005. "Is Air Pollution Impacting Winter Orograhic Precipitation in Utah?" Journal of Weather Modification 37: 14-20.

[42] Rosenfeld, D., and Givati, A. 2006. "Evidence of Orographic Precipitation Suppression by Air Pollution-Induced Aerosols in the Western United States." Journal of Applied Meteorology and Climatolology 45: 893-911.

[43] Painter, T. H., Barrett, A. P., Landry, C. C., Neff, J. C., Cassidy, M. P., Lawrence, C. R., McBride, K. E., and Farmer, G. L. 2007. "Impact of Disturbed Desert Soils on Duration of Mountain Snow Cover." Geophysical Research Letters 34: L12502.
[44] Reynolds, R. L., Goldstein, H. L., Moskowitz, B. M., Bryant, A. C., Skiles, S. M., Kokaly, R. F., Flagg, C. B., Yauk, K., Berquo, T., Breit, G., Ketterer, M., Fernandez, D., Miller, M. E., and Painter, T. H. 2013. "Composition of Dust Deposited to Snow Cover in the Wasatch Range (Utah, USA): Controls on Radiative Properties of Snow Cover and Comparison to Some Dust-Source Sediments." Aeolian Research15 (12): 73-90.

[45] Kunkel, K. E., Palecki, M. A., Hubbard, K. G, Robinson, D. A., Redmond, K. T., and Easterling, D. R. 2007. "Trend Identification in Twentieth-Century U.S. Snowfall: The Challenges." Journal of Atmospheric and Oceanic Technology 24: 64-73.

[46] Bales, R. C., Dressler, K. A, Imam, B., Fassnacht, S. R., Lampkin, D. 2008. "Fractional Snow Cover in the Colorado and Rio Grande Basins, 1995-2002." Water Resources Research 44 (1): W01425.

[47] Fassnacht, S. R., and Derry, J. E. 2010. "Defining Similar Regions of Snow in the Colorado River Basin Using Self-Organizing Maps." Water Resources Research 46 (4): W04507.

[48] Julander, R. P. 2007. "Soil Surface Temperature Difference between Steel and Hypalon Pillows." In Proceedings of the Western Snow Conference, 165-9.

[49] Pan, M., Sheffield, J., Wood, E. F., Mitchell, K. E., Houser, P. R., Schaake, J. C., Robock, A., Lohmann, D., Cosgrove, B., Duan, Q., Luo, L., Higgins, R. W., Pinker, R. T., and Tarpley, J. D. 2003. "Snow Process Modeling in the North American Land Data Assimilation System (NLDAS): 2. Evaluation of Model Simulated Snow Water Equivalent." Journal of Geophysical Research 108 (D22): 8850.

[50] Serreze, M. C., Clark, M. P., and Frei, A. 2001. "Characteristics of Large Snowfall Events in the Montane Western United States as Examined Using Snowpack Telemetry (SNOTEL) Data." Water Resources Research 37 (3): 675-88.

[51] Cowles, M. K., Zimmerman, D. L., Christ, A., McGinnis, D. L. 2002. "Combining Snow Water Equivalent Data from Multiple Sources to Estimate Spatio-Temporal Trends and Compare Measurement Systems." Journal of Agricultural, Biological, and Environmental Statistics 7 (4): 536-57.

[52] Julander, R. P. 2005. "An Analysis of the Timing of Snow Course Measurement and the Potential Error Compared to April 1 Measurement in Utah." In Proceedings of the Western Snow Conference, 131-7.

[53] Pagano, T. 2012. "Quantification of the Influence of Snow Course Measurement Date on Climatic Trends." Climate Change 114: 549-65.

[54] Pagano, T., Garen, D., and Sorooshian, S. 2004. "Evaluation of Official Western U.S. Seasonal Water 
Supply Outlooks, 1922-2002." Journal of Hydrometeorology 5: 896-909.

[55] Natural Resources Conservation Service. 1984. Snow Survey Sampling 20. http://www.wcc.nrcs.usda.gov/factpub/ah169/ah169.htm.

[56] Powell, D. R. 1987. "Observations on Consistency and Reliability of Field Data in Snow Survey Measurements." In Proceedings of the Western Snow Conference, 69-77.

[57] Natural Resources Conservation Service. Snow Telemetry (SNOTEL) and Snow Course Data and Products. http://www.wcc.nrcs.usda.gov/snow/.

[58] Kay, C. E. 2003. Long-term Vegetation Change on Utah's Fishlake National Forest: A study in Repeat Photography. Utah State University: Extension.

[59] Willmore, P., and Fraughton, D. 1936. "The Snow Courses of Utah: 1936." In Field Notes for 1936 Snow Courses, 509. Utah Cooperative Snow Surveys

[60] Natural Resources Conservation Service, Monthly snow data:

http://www3.wcc.nrcs.usda.gov/nwcc/snow-course-sites.j sp? state $=$ UT.

[61] Brown, A. E., Zhang, L., McMahon, T. A., Western, A. W., and Vertessy, R. A. 2005. "A Review of Paired Catchment Studies for Determining Changes in Water Yield Resulting from Alterations in Vegetation.” Journal of Hydrology 310: 28-61.

[62] Natural Resources Conservation Service, http://www.nrcs.usda.gov/Internet/FSE_DOCUMENTS/n rcs141p2_033131.pdf.

[63] Steppuhn, H., Stumborg, M., Lafibd, G., and McConkey, B. 2009. "Managing Snow Covers in Grain Fields Harvested for Straw Fiber." In Proceedings of the Western Snow Conference, 103-14.

[64] Fassnacht, S. R., Dressler, K. A., and Bales, R. C. 2003. "Snow Water Equivalent Interpolation for the Colorado River Basin from Snow Telemetry (SNOTEL) Data." Water Resources Research 39 (8): 1208.

[65] Gillan, B. J., Harper, J. T., and Moore, J. N. 2010.
"Timing of Present and Future Snowmelt from High Elevations in Northwest Montana." Water Resources Research 46: W01507.

[66] Murphy, K. W., and Ellis, A. W. 2014. “An Assessment of the Stationarity of Climate and Stream Flow in Watersheds of the Colorado River Basin." Journal of Hydrology 509 (13): 454-73.

[67] Cayan, D. R. 1996. "Interannual Climate Variability and Snowpack in the Western United States." Journal of Climate 9: 928-48.

[68] Hunter, T., Tootle, G., and Piechota, T. 2006. "Oceanic-Atmospheric Variability and Western U.S. Snowfall.” Geophysical Research Letters 33: L13706.

[69] Timilsena, J., and Piechota, T. 2008. "Regionalization and Reconstruction of Snow Water Equivalent in the Upper Colorado River basin.” Journal of Hydrology 352: 94-106.

[70] Natural Resources Conservation Service, Long Term Snow Data Comparison, http://www.nrcs.usda.gov/wps/portal/nrcs/detail/ut/snow/ ?cid=nrcs141p2_034246.

[71] Utah Snow Survey Contact Information, http://www.nrcs.usda.gov/wps/portal/nrcs/detail/ut/snow/ ?cid=nrcs141p2_034205.

[72] U.S. Geological Survey, GAGES-II: Geospatial Attributes of Gages for Evaluating Streamflow, http://water.usgs.gov/GIS/metadata/usgswrd/XML/gagesI I_Sept2011.xml.

[73] Harpold, A., Personal Communication, February 2014.

[74] Saunders, S., and Maxwell, M. 2005. Less Snow, Less Water: Climate Disruption in the West. Rocky Mountain Climate Organization, A Clear the Air Report, Louisville, Colorado.

[75] Wi, S., Dominguez, F., Durcik, M., Valdez, J., Diaz, H. F., and Castro, C. L. 2012. "Climate Change Projection of Snowfall in the Colorado River Basin Using Dynamical Downscaling." Water Resources Research 48: W05504. 